\title{
Phylogenetic analysis of stemmed points from Patagonia: Shape change and morphospace evolution
}

\author{
Marcelo Cardillo, Judith Charlin \\ Consejo Nacional de Investigaciones Científicas y Técnicas, Instituto Multidisciplinario de Historia y Ciencias \\ Humanas, Universidad de Buenos Aires, Saavedra 15 th floor, 1083ACA, Ciudad Autónoma de Buenos Aires, \\ Argentina. Email: Cardillo: marcelo.cardillo@gmail.com; Charlin: judith.charlin@gmail.com
}

\begin{abstract}
:
This work is focused in the study of Patagonian lithic projectile points shape variation from a phylogenetic perspective pursuing three main aims: first, generate a model of projectile point shape diversification and morphospace evolution; second, estimate shape variation through time, and finally, assess the robustness of previous results using the same methods but in a larger sample with better spatial coverage. A previous work using geometric morphometric and cladistic methods suggested a pattern of general morphological diversification across Patagonia related, at least in part, to the spatial distance between cases, distinguishing two main clades in northern $\left(43-45^{\circ} \mathrm{S}\right)$ and southern $\left(50-52^{\circ} \mathrm{S}\right)$ Patagonia. In the present work to study this pattern in a more detailed level, a sample of $c a .1200$ projectile points was used to obtain statistically different morphological classes performing unsupervised K-means searching. Shape characters were used to describe the different taxonomic units and to perform the phylogenetic analysis (through the Neighbour Joining and Maximum Parsimony methods) using as an ancestor the earliest point type known to the region (Fishtail point). The new results suggest that projectile points with longer and narrow blades and smaller stems evolved later in Patagonia and occupy a different sector of morphospace that could be related to the emergence of different technical systems, like the bow and arrow. However, these results do not support the previous ones of a projectile point diversification pattern mediated by spatial distance, maybe due to the reduction of contrast between the extreme north and south of Patagonia by the larger spatial coverage used in the present analysis.
\end{abstract}

Keywords: stemmed projectile points; phylogeny; geometric morphometrics; Patagonia; shape change; evolution

\section{Introduction}

\subsection{Phylogenetic perspective of projectile point shape evolution}

It was shown that phylogenetic reconstruction is a useful tool to generate hypotheses regarding tempo and mode of technological change (O'Brien et al. 2001; O'Brien \& Lyman 2003; Lipo et al. 2005; O'Brien et al. 2005, Cardillo 2009; García Rivero \& O'Brien 2014; among others), under the assumption that culture conforms and evolutionary system with a

Published by the School of History, Classics and Archaeology, University of Edinburgh ISSN: 2055-0472. URL: http://journals.ed.ac.uk/lithicstudies/ 
hierarchy of genealogical units analogous to the genealogical hierarchy of organic evolution (Boyd et al. 1997). Due to cultural transmission processes, artefacts are able to evolve in lineages that can be documented by different phylogenetic methods. For example, approaches like maximum parsimony, distance-based, maximum likelihood and Bayesian statistics have been applied to explore hypothesis about the evolution of basketry (Jordan \& Shennan 2009), tapestry motifs (Tehrani \& Collard 2002), ceramics (Harmon et al. 2006; Pardo Gordó et al. 2018), lithics (Buchanan \& Collard 2007; 2008; 2010; Cardillo 2009; Darwent \& O'Brien 2006; Lycett 2009; Mesoudi \& O’Brien 2008a; 2008b) and linguistics (Atkinson et al. 2008; Gray \& Atkinson 2003). While techniques of phylogenetic analysis are different -since some of them are related to specific hypotheses about rates of change- the basic principle for application is based on the observation that culture constitutes an independent system of inheritance (but in many cases related to genetic one) (Cavalli-Sforza \& Feldman 1981; Durham 1992).

The main strength of the cladistic method is its dependence for phylogenetic reconstruction on homologous traits, separating them from those analogous (Kitching et al. 1998). By definition, homologous traits are those shared traits inherited from a common ancestor. Instead, analogous traits are those forms that evolved independently in unrelated lineages. In cladistic terms, the former constitute the so-called synapomorphies, or inherited similarities, whereas the latter are homoplasies (Kitching et al. 1998; see also Collard 2006; O'Brien \& Lyman 2003). The purpose of cladistics is to build hypothetical evolutionary relationships among taxa by documenting the branching structure between these taxa, distributed in related groups called clades and forming a tree-like pattern. So, cladistics assumes that the evolutionary process takes place by the binary divergence between classes increasingly derived from a hypothetical ancestor. Thus the quantity of homoplasy (analogous variation) in a dataset informs the degree to which the evolution of certain taxa cannot be explained by the tree-like model of branching divergence. These homoplasies are the result of convergence and other evolutionary processes such as reversion and parallelism but not of inheritance. As homoplasy increases, the phylogenetic signal of a dataset declines. The strongest of the phylogenetic signal of a given dataset is assessed by different goodness of fit measures to the branching pattern.

\subsection{Shape spaces and phylogenies}

The form (size plus shape) of projectile points is usually used as a classification tool to characterize the variation of these artefacts in time and space (Beck 1998; Bettinger \& Eerkens 1999; O'Brien et al. 2001; O’Brien \& Lyman 2003; Okumura \& Araujo 2014). Thus, morphological variations over time are often explained by changes in the strategies for obtaining resources (Hughes 1998; Ratto 2003; Restifo 2013, among others), or by the existence of particular traditions in design selection, without this necessarily having any functional implications.

In artefacts so directly related to subsistence through energy capture, like projectile points, it is expected that the morphological variability reflects (at least to a limited extent) functional restrictions (such as cutting capacity, penetration, etc.) as well as the interdependence between structural aspects (such as weight, raw materials, symmetry, hafting requirements), which will not be the same for the different technical systems (Ratto 1990; 1991; 1994; Hughes 1998; Shott 2011). In this scenario of correlation between the different structural and morphological factors, it is expected that the evolutionary trajectories preferentially follow some ones over others (Cardillo 2009). On the contrary, if these restrictions do not exist, it would be expected that all the potential morphological variation was made over time. Within a phylogenetic perspective like the one proposed in this paper, it 
is expected that in the absence of restrictions, the different clades have the same rate of diversification over evolutionary time when they are represented within the morphological space. Kindemberg (2010) refers to the first scenario as one of total or partial morphological restrictions, while the second would have no restrictions.

On the other hand, if there were restrictions, diversification would not occur in an equivalent way throughout the morphological space but would be greater around certain design combinations. This would be more in line with the existing evidence for a large number of technologies, as demonstrated by Basalla (1998). Neither these design spaces would be fixed, but it is expected that these types conform lineages (evolutionary trajectories of types connected by descent with modification) displaced over time in relation to changing functional requirements favoured by selection. Although in general it is expected, as mentioned above, that these changes are made in preferential directions or regions of the design space (Cardillo 2009).

One way to approach this phenomenon is from the study of morphological spaces (or morphospaces) as an approximation to the general design of the lithic projectile points. The morphological spaces are by their nature continuous and multidimensional, so it is common to generate them from multivariate methods (see for example, McGhee 1999). In the case they are estimated by a specific number of real cases, these spaces will be of an empirical nature (McGhee 1999) and its amplitude will be, at least in part, a function of the morphological variation present in the dataset. Another possibility is to generate theoretical spaces from morphologies defined by geometric functions. In this case the spaces are not determined by empirical variation and are especially useful for complex morphological variables that involve numerous dimensions (McGhee 1999; 2015). In our case study, we will use empirical spaces generated from geometric morphometrics. Although empirical spaces have limitations, they will be more robust as the sample size increases. This allows representing the phylogeny within a morphological space and, in this way, generating a visual representation of the diversification path of the lithic projectile points over time. In this context, evolutionary change is represented, as Klinberg (2010) refers to as paths of ancestors to descendants within morphospace. The patterns of occupation and displacement of the ancestors-descendants of projectile points within the morphospace thus provide information about the evolutionary dynamics of shape. Some sectors of the total design space may present more restrictions than others, so various patterns are expected in relation to this (McGhee 1999; Sidlauskas 2008; see also Gould 1989 about constraints in evolution). Therefore, it is possible that some tree branches have more potential to generate new classes (greater diversity) than others, but with less global morphological variation. Within this scenario, certain clades will occupy more restricted spaces where less potential variation is feasible (for example, by functional constraints). In this case morphological channelling is expected and, therefore, an imbalance in the way in which this morphospace is occupied. Alternatively is possible that the morphological space is occupied homogeneously and all the sectors present the same probability of diversification. In this second scenario, the restrictions on the potential for morphological diversification are minor, irrespective of their diversity of classes (Figure 1).

This is in accordance with what was proposed by Sidlauskas (2008) about the evolution of the morphological space, in which there is a scenario where the lineages within the clades with high morphological diversity experienced a higher diversification rate per branch and a second scenario where the exchange rate is equivalent for all the clades but the greatest morphological diversity is linked to the exploration (mode) of new morphospace regions. This means that in one case the high diversity of classes is accompanied by a high morphological variation (disparity) and in the other both are decoupled. 


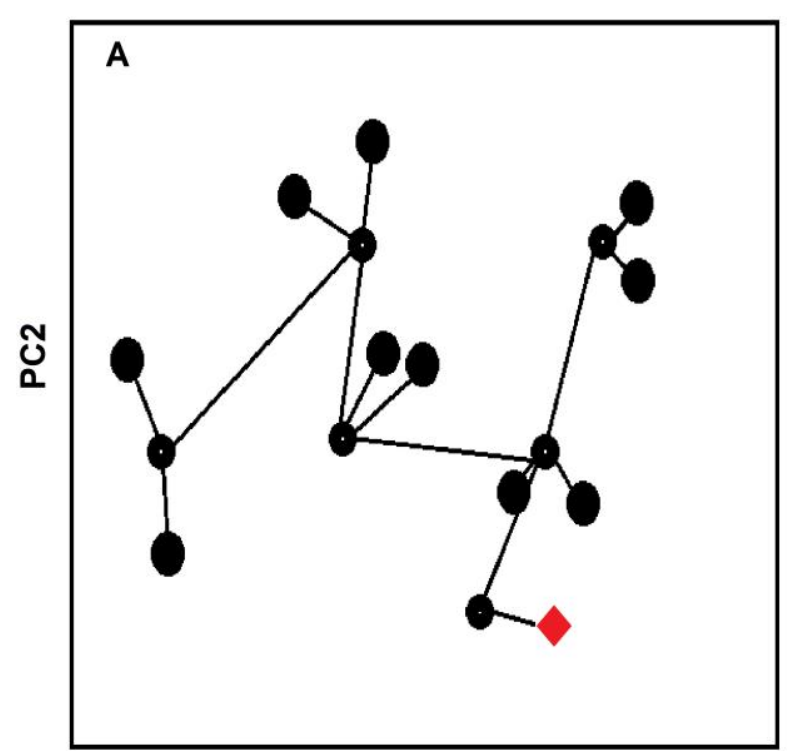

PC1

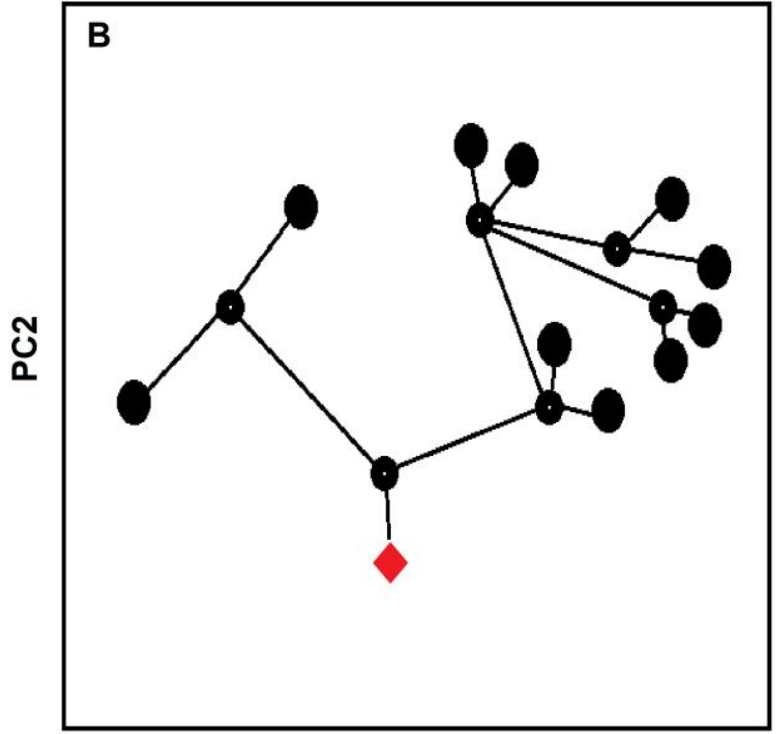

PC1

Figure 1. Two possible scenarios of morphospace filling in two dimensional axes from a Principal Component (PC) Analysis in a phylogenetic perspective. A) homogeneous, B) heterogeneous.

\subsection{Previous research on projectile point shape variation since a phylogenetic perspective}

Patagonia is the southern tip of South America, covering a spatial scale of $c a .1500 \mathrm{~km}$ between $39^{\circ}$ (Colorado river) and $52^{\circ}$ (northern coast of strait of Magallanes) of South latitude. It is characterized by the presence of Andean Cordillera in the west and plateau and low plains in the east. The regional climate is conditioned by temperature gradient which decreases southward (Clapperton 1993). The earliest evidences for human occupations at different places across Patagonia is dated to $c a$. 10-12000 BP (Bird 1938; 1946; 1988; Borrero 1994-1995; 2015; Borrero \& Franco 1997; Massone 1987; 2004; Miotti 1995; 1996; Nami 1985-1986; 1987; Prieto 1991). These hunter-gatherer populations had a diet mainly centered in guanaco (Lama guanicoe) hunting and a lithic technology well-known by the presence of Fishtail points (Bird 1938; 1946; 1988; Hermo \& Terranova 2012; Hermo et al. 2015; Miotti 1995; 1996; Massone 1987; 2004; Mengoni Goñalons 1987; Nami 1985-1986; 1987; Politis 1991, among others). From the Middle Holocene and especially during the Late Holocene stone points from Patagonia show a wide range of metric and morphological variation. Many of these changes are related with functional diversity, use-life, hafting techniques, and spatial and temporal variations, among others (Álvarez 2011; Banegas et al. 2014; Cardillo \& Alberdi 2015; Cardillo \& Charlin 2016; Cardillo et al. 2016; Charlin \& Cardillo 2018; Charlin \& González-José 2012; Charlin et al. 2013; 2014; Franco et al. 2005; 2009; 2010; Gómez Otero et al. 2009; González-José \& Charlin 2012; Nami 1986; 1988; 2003; Ratto 1990; 1991; 1994).

From a phylogenetic framework, in a previous work we analyzed late Middle and Late Holocene stemmed points shape variation with the aim to explore how spatial dimension mediates on the process of point shape diversification (Cardillo \& Charlin 2016). We studied a sample of 301 complete stone points recovered from continental Patagonia between $40^{\circ}$ and $52^{\circ}$ of South latitude, which was separated in six groups according to latitudinal strips. Through geometric morphometrics, mean shapes by strip were obtained, which were then used in cladistic analysis to model diversification trends.

These analyses showed a pattern of general morphological diversification related to the spatial distance between groups, showing a geographical gradient from north to south. Two 
large groups of morphologies with similar deformation patterns were distinguished in Northern $\left(43^{\circ}-45^{\circ} \mathrm{S}\right)$ and Southern Patagonia $\left(50^{\circ}-52^{\circ} \mathrm{S}\right)$. While point shape of higher latitudes showed a more uniform pattern, at middle and low latitudes a greater variability was observed.

These results suggested that variability in late Middle and Late Holocene point morphology could be explained by the occurrence of geographical (spatial) and historical macroscale-related mechanisms. The divergence into two large groups appeared as a phenomenon channelled by spatial distance and related to mobility and information flow among human populations since spatial model explained $79 \%$ of phylogenetic variability (Cardillo \& Charlin 2016). This process was related with the Santa Cruz River $\left(50^{\circ} \mathrm{S}\right)$ functioning as a biogeographic barrier, like the distribution of other lines of evidence had also suggested (Borrero 2001; Cardillo 2011; Charlin \& Borrero 2012; Franco 2002; Orquera 1987).

Given the considerable environmental variability in Patagonia, the pattern we had observed might be also linked to ecological mechanisms since the Patagonian environment is highly conditioned by latitude (Clapperton 1993). Thus, it may be expected that point design was influenced by performance requirements in different environments. Pursuing this aim, Cardillo et al. (2016) assessed the correlation between spatial and environmental variables (precipitation and temperature) and point morphological change, enlarging the sample up to 1445 stemmed points, including insular Patagonia (samples from the Isla Grande of Tierra del Fuego in southernmost Patagonia). A global trend for the distribution of shapes according to environment was not observed at this largest scale. Contrarily, the results showed a pattern of high morphological variation in lithic points in a local or micro-regional scale across overall Patagonia. This phenomenon is similar to that recorded by other lines of evidence, such as the distribution of raw materials (Alberti \& Cardillo 2015; Alberti \& Fernández 2015; Borrazzo 2012; Charlin 2009; Cirigliano et al. 2018; Franco 2002), flake vs. blade technologies (Charlin et al. 2011; Franco 2008; Franco et al. 2016; Pallo \& Cirigliano 2018), coastal technologies (Cardillo 2011), rock art (Charlin \& Borrero 2012 and references therein) and diet breadth (Barberena 2002; 2008; Barberena et al. 2009; Borrero \& Barberena 2006; Borrero et al. 2001), which suggest an increase in the regionalization of human populations, especially in the Late Holocene.

\subsection{Aims}

In order to study the Patagonian projectile points morphological diversification in a more detailed level, our aims here are: first, generate a quantitative model of Patagonian stemmed point evolution through phylogenetic reconstruction based on shape variation; second, estimate shape variation through time, and finally, assess the existence of correlation between the diversification pattern and the spatial distance between the classes, as previously research showed (Cardillo \& Charlin 2016).

\section{Materials and methods}

\subsection{Sample composition}

The studied sample is composed by 1197 complete stemmed points from overall continental Patagonia (Figures 2 \& 3). According to sample density, southern continental Patagonia, especially the Pali Aike volcanic field region (Santa Cruz Province, Argentina and Magallanes, Chile), is better represented than other northern areas since several previous works were focused there (Charlin \& González-José 2012; Charlin \& Cardillo 2018; de Azevedo et al. 2014; González-José \& Charlin 2012). 


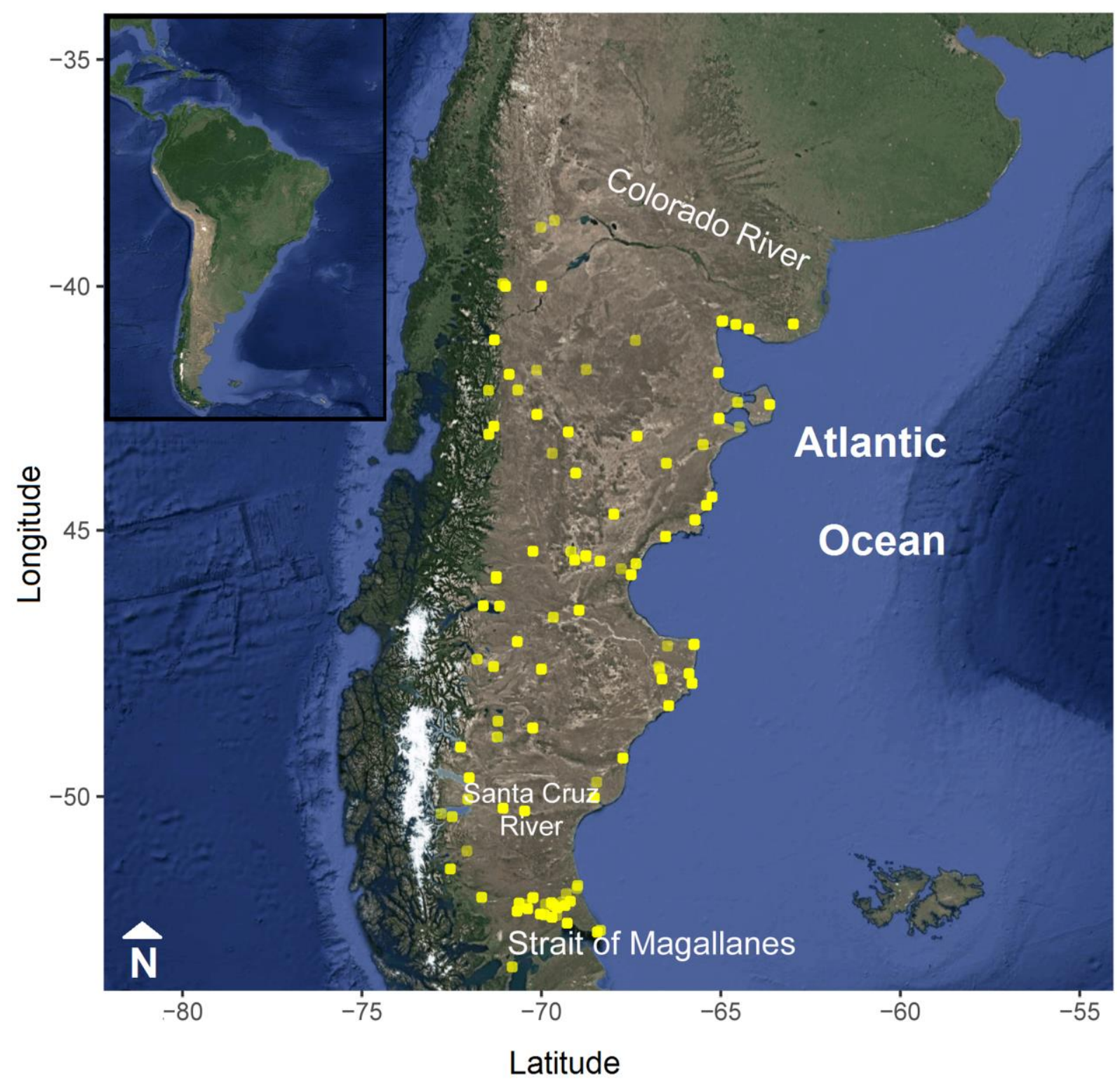

Figure 2. Distribution of projectile point samples across Patagonia. Figure obtained by ggmap 3.0 package (R developed core team 2015)

The whole sample is composed by non-Fishtail stemmed points belonging to late Middle and Late Holocene and come from our research projects, an extensive survey of museum collections and published images taken from local literature.

\subsection{Methods}

\subsubsection{Geometric morphometrics}

Geometric morphometrics (GM hereafter) is the statistical analysis of form based on Cartesian landmark coordinates (Adams et al. 2013; Bookstein 1991; Mitteroecker \& Gunz 2009; Slice 2007; Webster \& Sheets 2010). In the last years this method has been increasingly applied to the study of stone tools form (de Azevedo et al. 2014; Buchanan \& Collard 2010; Buchanan et al. 2014; 2015; Cardillo 2010; Cardillo \& Charlin 2016; Cardillo et al. 2016; Castiñeira et al. 2012; Charlin \& González-José 2012; Charlin et al. 2014; González-José \& Charlin 2012; Iovită 2011; Iovită \& McPherron 2011; Lycett et al. 2010; 2013; Morales et al. 2015; Okumura \& Araujo 2014; Shott \& Trail 2010; 2012; Thulman 2012, among others). 

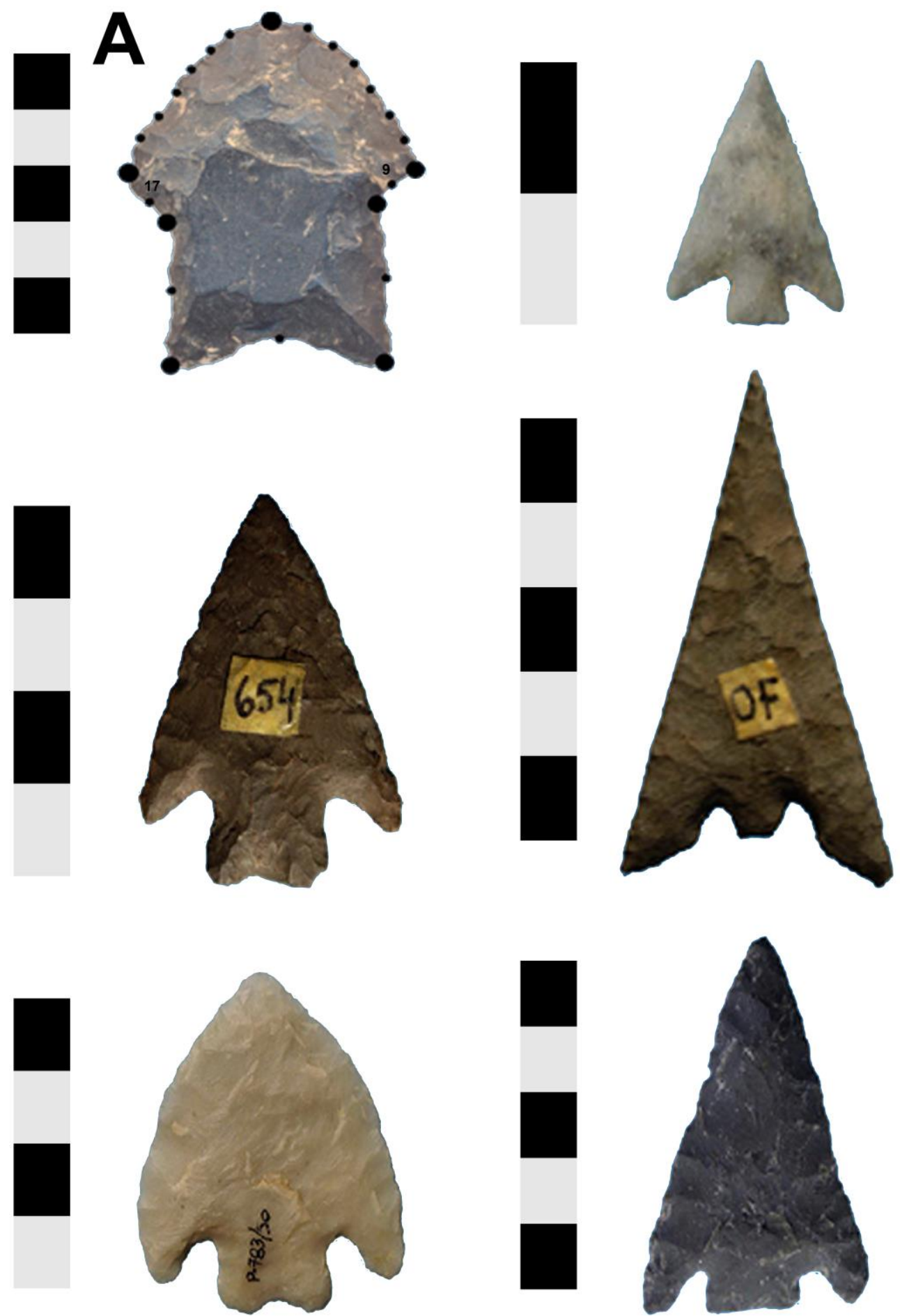

Figure 3. Variation in Patagonian projectile point shapes. A: projectile point showing the location of landmarks (big dots) and semilandmarks (small dots). Semilandmarks 9 and 17 were left aside to Maximum Parsimony tree searching (see below). Scale bars are divided into $1 \mathrm{~cm}$ segments.

The application of GM methods on stone tools allow representing their physical configuration (their size and shape) as a mathematical object by means of Cartesian coordinates (Mitteroecker \& Hutteger 2009). These methods also allow quantification of variation in size and shape as separate variables in the absence of allometry (Zelditch et al. 2004), which is a great advantage over traditional methods, since they usually studied the shape of artefacts through linear measurements that are in most of the cases highly correlated among them and with size (Bookstein 1991). Thus, these measures actually describe form 
(size+shape) rather than shape and provide largely redundant information (Iovită 2010; Shott \& Trail 2010). In morphometrics, the term shape denotes the geometric properties of an object invariant to scale, position and orientation, whereas form comprises both its shape and size (Bookstein 1991; Mitteroecker \& Gunz 2009; Mitteroecker \& Huttegger 2009). Hence, through GM it is possible to perform multiple statistical analyses to assess projectile point size and shape change.

In GM the form of an object is captured by discrete points called landmarks and semilandmarks. The most important property of the former is their homology, either in light of a biological or geometrical principle (Bookstein 1991). When homologous points are difficult to identify, like in curved outlines (e.g., projectile point blades or end-scraper edges), semilandmarks are used (Bookstein 1997). They are arbitrary points defined in terms of its position on curves and surfaces used to capture homologous structures where isolated anatomical or geometric loci are not evident. The arbitrary spacing of semilandmarks can be controlled by sliding them following different procedures and algorithms (see Bookstein 1997; Gunz \& Mitteroecker 2013; Gunz et al. 2005; Perez et al. 2006).

In landmark-based methods shape parameters are estimated by a Procrustes superimposition procedure (the Generalized Procrustes Analysis, GPA), that translates the original forms to a common origin, scales them to the same centroid size, and rotates them using a least-squares criterion (Rohlf 1990; Rohlf \& Slice 1990). In this way, the GPA removes the effects of translation, rotation, and scaling, which results in shape coordinates free of variations in position, orientation, and size.

In this analysis we used 24 morphometric points located on the contour of the projectile points in order to achieve a good representation of their shape: they comprise seven landmarks located in homologous loci according to stemmed point design and 17 semilandmarks in projectile point curved sections (especially on blade outline) and in the middle-point between landmarks in shoulders and stem portions without distinguishable morpho-technical traits (Figure $3 \mathrm{~A}$ ).

The arbitrary spacing of semilandmarks was removed by sliding them following the minimun bending energy criterion (Bookstein 1997).

Landmark configurations were superimposed performing a GPA using the tpsRelw (ver. 1.69) software (Rohlf 2017). After superimposition, pure shape information (named in general Procrustes or shape aligned coordinates) was obtained to be used in cladistic analyses.

\subsubsection{Definition of morphological types}

As many experimental and allometric studies have shown, artefact shape variation is a continuous phenomenon (Andrefsky 2006; Bettinger \& Eerkens 1999; Bettinger et al. 1991; Bradbury \& Carr 2003; Buchanan 2006; Buchanan \& Collard 2010; Dibble 1984, 1987; Flenniken \& Raymond 1986; Flenniken \& Wilke 1989; Hiscock 1994, 2006, 2007; Hiscock \& Attenbrow 2002, 2003, 2005; Hiscock \& Veth 1991; Hunzicker 2007; Morrow \& Morrow 2002; Shott \& Ballenger 2007; Shott et al. 2007; Towner \& Warburton 1991). However, phylogenetic analysis require a set of types or classes described by characters (discrete or continuous) to build a tree. Therefore, to define different discrete entities (classes) in a continuous distribution could be a difficult task and, in some cases, a very subjective one. Moreover, in stone tools like arrowheads, discrete shape classes, if exist, are affected by replicative errors, mechanical differences in the knappable materials used, as well as by the life history. In fact, in a previous work Charlin \& Cardillo (2018) showed evidence that the morphological variation in stemmed projectile points from southern Patagonia was affected by rejuvenation processes (see also Charlin \& González-José 2012), which result -in evolutionary terms- in shape convergence, since they generate morphological equifinality 
among projectile points from different technical systems and chronological contexts (Charlin \& Cardillo 2018). For all these reasons we considered classes as hypothetical operational taxonomic units (OTUs) in the sense of Dunnell (1989), which would carry information about life history. These kinds of units are useful in the cases in which obvious discontinuities are not directly observable, as often happens in continuous features. To derive OTUs, we perform unsupervised K-means group searching in the morphological space defined by all Procrustes aligned specimens (shape coordinates of projectile points).

K-means is a simple automatic learning algorithm that is used to solve clustering problems. The goal of K-means clustering is to find groups in the dataset, where $\mathrm{K}$ represents the number of groups to be defined. The algorithm works iteratively to assign each data point to one of $\mathrm{K}$ groups based the observed similarities in the data matrix (in this case the shape matrix). Hence, we first perform a gap statistic to estimate the optimal number of groups (Charrad et al. 2014). Gap statistics is a method to find the gap in the continuous multivariate distribution which defines the minimum number of possible groups. To achieve a stable solution 500 bootstrap replications of the searching processes were made. A minimum of 1 and a maximum of 20 groups were set for K-means algorithm searches. Once the optimal number of clusters was found, 30 interactions of the K-means were allowed in order to accurately define group centroids and boundaries. After this, the mean difference between groups was tested by permutational MANOVA using 10000 bootstrap replications (Anderson 2001) at a significance level of $\alpha=0.05$. In order to decrease the chance of committing type 1 error in-between-group comparison, p-values were adjusted with Bonferroni method at $\alpha / \mathrm{n}$, where $\mathrm{n}$ was the number of groups to being compared. More information about the analyses can be found in the attached R script file 1 and 2 of supplementary material.

\subsubsection{Phylogenetic analyses}

For phylogenetic reconstruction, the mean shape of each cluster was used as an operational unit to build a phylogenetic tree through two phylogenetic reconstruction methods: one based on distances and other on maximum parsimony. The Neighbor Joining method (NJ), which is a distance-based phylogenetic tool (Saitou \& Nei 1987), was used in previous research by the authors (Cardillo \& Charlin 2016) with overall good results. Although the method is similar to cluster analysis (in the sense that it uses total similarity as input of the clustering processes), $\mathrm{NJ}$ is considered a minimum evolution algorithm, because minimizes the total amount of change as well as other phylogenetic methods. The tree can also be polarized to indicate the direction of change. Moreover, experimental studies show that NJ is either effective in recovering the true phylogeny or in many cases is significantly closer to the actual tree (Atteson 1997; Gascuel \& Steel 2006; Mihaescu et al. 2009). In this context homoplasies are related to additivity. For distances to fit into an NJ tree, they must achieve this condition (also called four point condition, Saitou \& Nei 1987). When estimated distances generate lineages that go backwards, the method fails to produce a correct evolutionary tree.

The result of NJ reconstruction is only one fully resolved tree, while other methods such as Maximum Parsimony, can generate an indeterminate number of more parsimonious trees (see below). Bootstrap resampling is a common method to measure the uncertainly in tree reconstruction. In this case, the support of each clade was evaluated by bootstrap resampling 10000 times and subsequently the majority consensus was estimated. Majority consensus is represented onto a composite tree (Figure $4 \mathrm{~B}$ ) that represents uncertainly related to the phylogenetic hypothesis about branching model of divergent evolution. The branches supported by less than $50 \%$ of the bootstrap interactions were collapsed and represented as unresolved. These unresolved ancestral relations occur when an internal node of a cladogram 
has more than two immediate descendants and shown as nodes (branching points) with three or more branches that appear simultaneously, what is called polytomies.

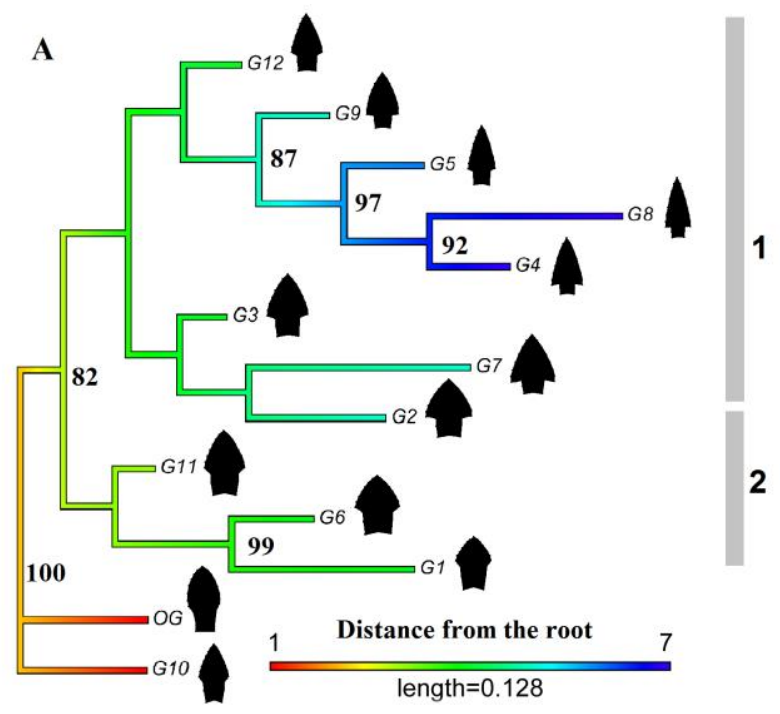

B
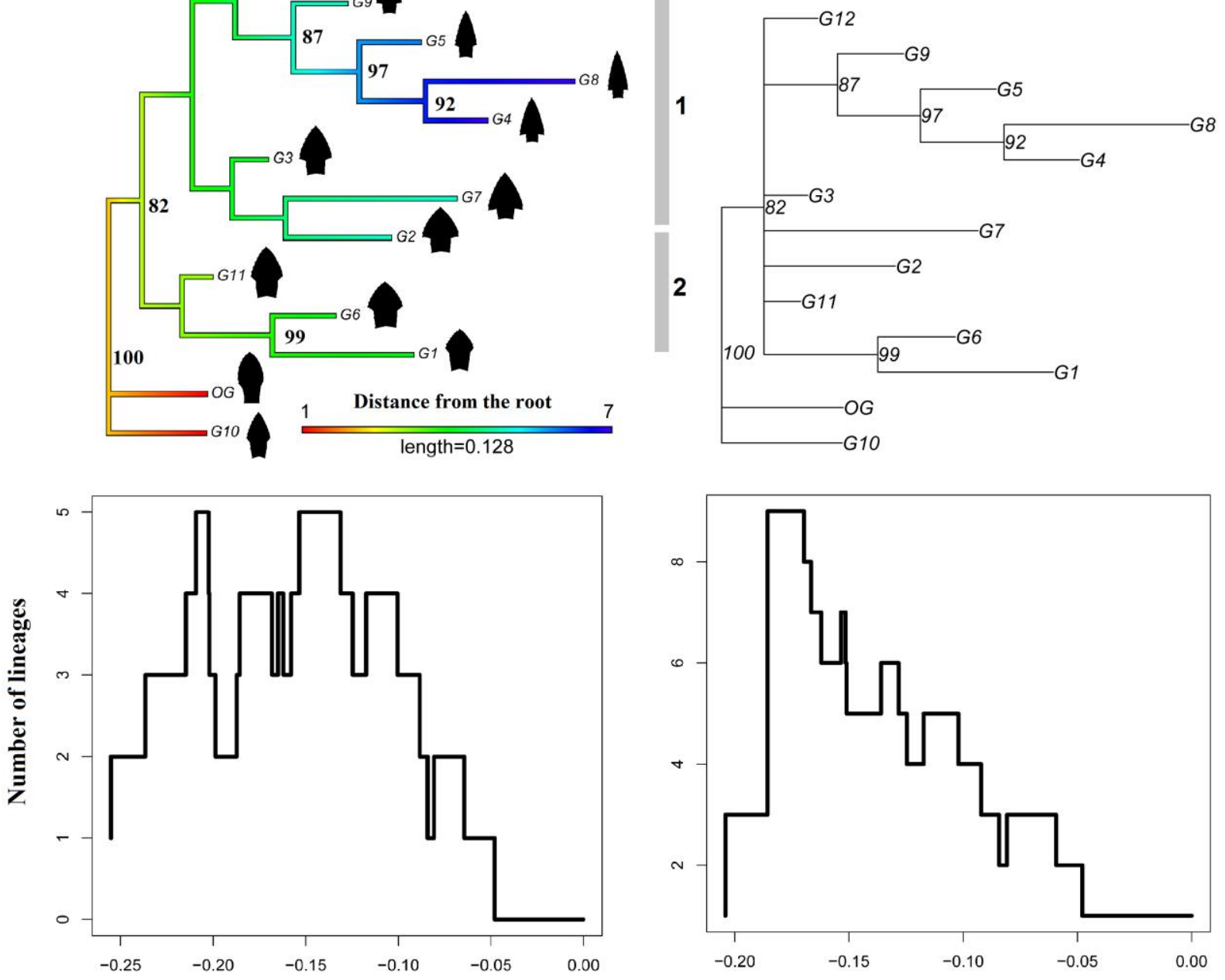

Time

Figure 4. Resolved (A) and consensus (B) tree. Resolved tree also shows a distance scale from root to tips. At the bottom: corresponding lineages through time plots to each tree. In resolved tree A, the main clades with high support measure $(82 \%)$ are shown (grey bars 1 and 2 ).

Since the tree obtained is additive, the length of the branches implies an amount of evolutionary change. Both resolved and consensus tree were used to plot lineage to time trajectories (Nee et al. 1995), which are bivariate graphs that represent accumulation of species number against branching times. This plot depicts the pattern of diversification throughout the evolutionary time (which is defined from the distance between tree branches from root to tips). While this method function is mainly for exploratory analyses, their plots are useful to explore the relationship between diversification and extinction ratios, because concave exponential curves (linear under logarithmic transformation) is expected under constant diversification rates (Nee et al. 1995). In this case, we present the number of untransformed scale, since no significant differences were observed between the two methods and the raw frequencies are easier to interpret (see Figure 4).

However, one of the most known pitfalls of $\mathrm{NJ}$ is that character identity is loss due to the use of a "secondary" pairwise distance matrix. So, shared evolutionary novelties (synaphomorphies) or independent evolution (homoplasy) in a set of characters cannot be 
evaluated directly. On the contrary, with the Maximum Parsimony (MP) method the phylogenetic tree that minimizes the total number of character state changes is to be preferred, and perhaps for this reason is the most common method of phylogenetic reconstruction in general and the more widely applied in archaeological research (see section 1.2). Unlike distance-based methods, a result of a maximum parsimony search could be one or more most parsimonious trees with similar number of steps. Also, character mapping onto the tree allows reconstruct ancestral states, as well as estimate the degree of homoplasy in each one. For this reason, the main objective in using this method is to compare with the results obtained through previously used procedures $(\mathrm{NJ})$ and to evaluate the degree of phylogenetic signal (as well as the homoplasy) contained in the shape. As we prefer a method that allows us to use metric and shape continuous characters as such, we select a method of phylogenetic reconstruction implemented for Catalano et al. (2010, also Goloboff \& Catalano 2011) in the TNT program (Goloboff et al. 2008; Goloboff \& Catalano 2016). Different recent research shows the good performance of parsimony reconstruction in the study of shape evolution using aligned landmark coordinates as characters (Catalano \& Torres 2017; Catalano et al. 2010; Goloboff \& Catalano 2011).

In this method, a set of landmarks is considered a configuration and is equivalent to one character. In this case the total set of landmark points could be considered the same configuration and used in the phylogenetic reconstruction. However, as was observed in experimental studies (Catalano et al. 2015; 2017), the robustness of the results increases as the number of configurations increases. For this reason, two configurations or sets of landmarks were isolated for this analysis: one defining the blade and other for the stem (see File 6 of supplementary material). A previous work aimed at assessing the modularity of southern Patagonia projectile point designs has shown the blade and the stem function as independent modules (González-José \& Charlin 2012). Even more important, the division of these two sections of the morphology allows us to evaluate the existence of a phylogenetic signal, as well as the degree of homoplasy in these configurations of shape independently. As mentioned above, we believe that this may allow to evaluate (in particular in the blade), the factor of convergence between classes, due in part to the life history of projectile points. To generate two separate modules, the landmarks number 9 and 17 were left aside, since they were in the middle of the two configurations (see Figure $3 \mathrm{~A}$ ). In the implementation of phylogenetic method with sets of landmarks considered directly as characters, the homoplasy is calculated as the difference between the observed and the minimum possible displacements of the landmarks, and therefore the minimum possible displacement for each character (landmark configurations) is calculated (see also Klindemberg 2010).

For the search of MP trees we use 1000 independent heuristic searches of Wagner trees and successive rearrangements with tree bisection and reconnection (TBR), which try all possible re-connections between edges of a tree in order to reduce tree length. Also a maximum of 100 of the best trees was stored in each run, and suboptimal trees were discarded only when a new tree with smaller number of steps was found. In this case, reliability of the results has been evaluated by means of 1000 replications of symmetric resampling (see Goloboff et al. 2003). Then ancestral character states of blade and stem configuration was reconstructed and degree of homoplasy for each one was computed.

To polarize both NJ and MP trees and give direction to the branching pattern, the mean shape of Fishtail points from Southern Patagonia was selected as out-group.

\subsubsection{Phylogenetic shape space}

The resulting tree of $\mathrm{NJ}$ was used for phylogenetic morphospace reconstruction (Sidlauskas 2008). Since we start from a tree constructed from shape coordinates, its 
representation within morphospace (determined by the principal component resulting from the OTUs, see File 4 of supplementary material) serves to represent the evolutionary trajectories of morphological change within space in a total way. As we explain in the section 1.2, this allows us to visualize which clades were more diversified in shape and which were not.

To assess the relationship between morphological diversification and spatial distance the average coordinates for each group was estimated and a distance matrix between them was generated. In parallel, the distance between branches of the tree without the out-group was calculated. Both distance matrices were correlated by means of the Mantel test. The p-value for the observed correlation was estimated by 10.000 permutations. More information about the analytic procedure can be found in the R script file 1 of supplementary material.

For OTU searching and phylogenetic analysis the package R 3.5.0 (R developed core team 2015) was used. Also, permutational MANOVA and the visualization of deformations by Thin-Plate-Spline were obtained with Past 2.14 (Hammer et al. 2001).

Supplementary material composed by an R script for main analysis steps (File 1), the aligned coordinates (File 2), mean shape for each group (OTUs, File 3), three main components of shape variation (File 4), mean spatial coordinates for each OTU (File 5) and TNT file for Maximum Parsimony searching with two shape configurations (File 6), are available online.

\section{Results}

\subsection{General shape trends}

Twelve groups were recognized first with the gap statistics and by K-means clustering on aligned shape coordinates (Figure 5). Permutational MANOVA with 10.000 bootstrap replicas and Bonferroni correction $(\mathrm{F}=280.8 \mathrm{p}=0.0001)$ suggest that all shape means are statistically different at $\alpha=0.05$ level. Between-pair comparisons are all significant at a corrected $\mathrm{p}$-value of $\mathrm{p}=0.007$.

First two principal components (PCs) showing main shape variations and the distribution of groups can be observed in Figure 5. They explain $80 \%$ of overall variation in projectile point shape. The first PC (PC1 58\%) shows projectile points with shorter and wider blades and bigger stem areas in the positive scores whereas longer and narrow blades with smaller stems are located in the negative scores. The second axis (PC2 22\%) shows wider blades with smaller stems in negative scores and narrow blades with longer stems in positive ones.

Some overlapping is observed in the $95 \%$ ellipses of the PC plot, but such overlap is partly related to the projection of the multidimensional group boundaries (where the search of the groups was carried out) onto a bidimensional space which we use here to represent the general variation trends.

\subsection{Tree reconstruction}

$\mathrm{NJ}$ gives one fully resolved tree (Figure $4 \mathrm{~A}$ ) with bootstrap support values at the bottom of each node. Results suggest two big clades (if taking into account a basal split with $82 \%$ bootstrap support). Clades with elongate shapes $(5 \mathrm{~A}, 1)$ have better resolution than clades mainly composed by wider and rounded blades (Figure 4 A, 2). These differences in support also can be seen in the majority consensus tree at the right of Figure 4 B. In the fully resolved tree we depicted the distance to the root on colour. More supported branches appear to be more distant to the root or more derived than the others, suggesting more evolutionary time. 


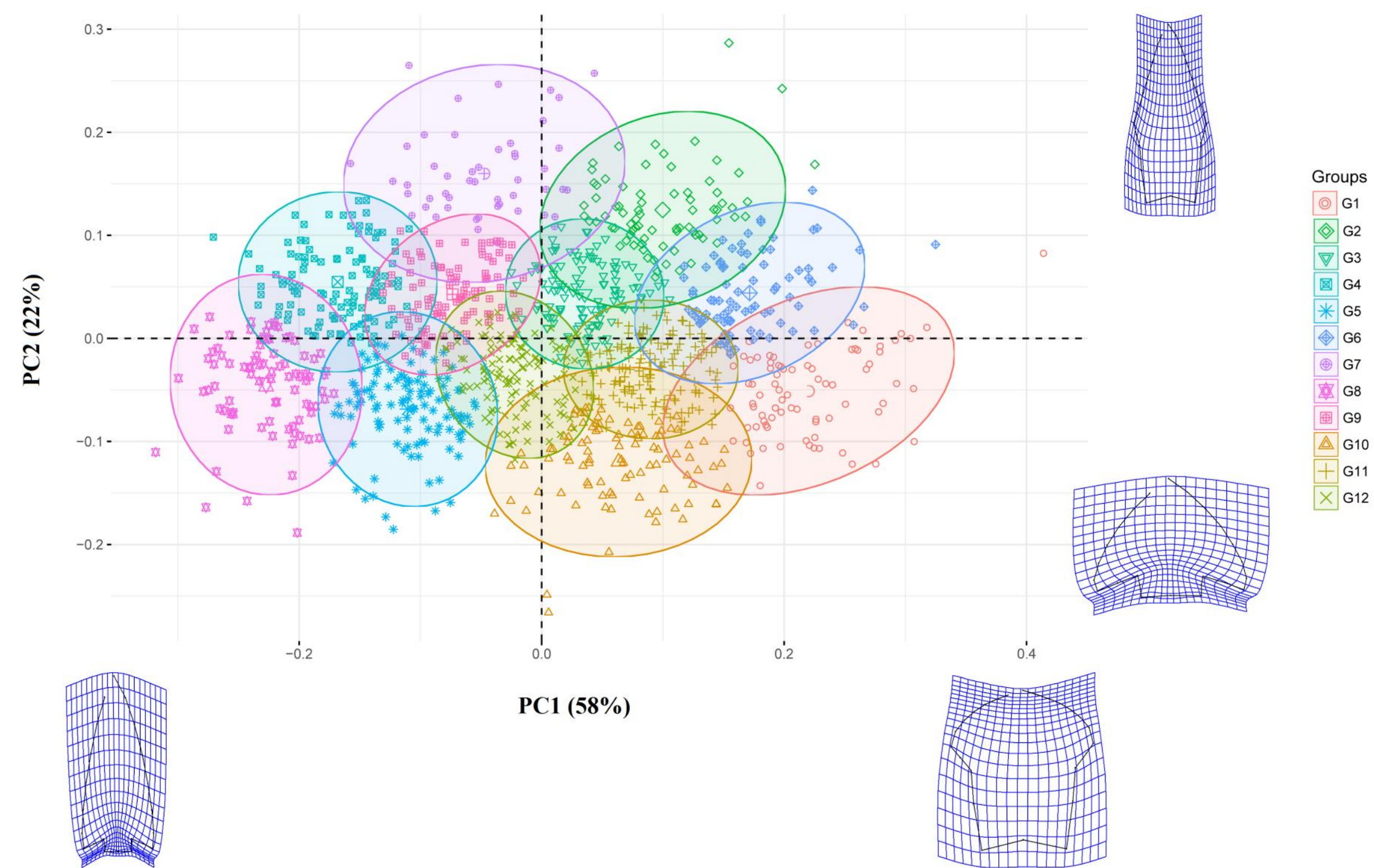

Figure 5. First two axes of principal component analysis on projectile points shape coordinates. Groups selected by K-means are depicted with $95 \%$ concentration ellipses. At the bottom: main shape deformation of first axis. At the right: the second axis shape deformations. 
Two lineages through time plots were estimated for each tree (resolved " $\mathrm{A}$ " and consensus "B" tree in Figure 4). In the first case, the plot suggests high diversification at the beginning followed by a high rate averaging the mean evolutionary time. In the second case, as low support branches were collapsed (values lower of $50 \%$ bootstrap), high diversification is depicted only at the beginning of the tree with a sudden fall for the remained evolutionary time, suggesting lower diversification rates.

A single tree was also obtained by the MP method (Figure 6). One interesting result is that this tree is very similar to that obtained by NJ (see Discussion). The only OTU in a different position is G5, which appears in an early node than in the NJ tree but in the same clade. Also group support is better than in NJ tree but in general those nodes with better support in the NJ tree also have high values in MP.

Likewise, the reconstruction of the configuration for blade and stem shows two main tendencies: one less derived closest to the out-group of robust forms, with more rounded blades with expanded stems (in particular stem neck) and another more derived towards more contracted stems and expanded blades with more lateral compressed stems, which also defines G4 that comprises barbed and expanded blade shapes, an evolutionary novelty not shared with G8 or other members in any clade (autopomorphy, see discussion).

Overall results and resampling supports suggest that blade shape carry with phylogenetic information. However the overall homoplasy for blade configuration is 3.29 , or 2.42 times greater than the stem (1.36). This pattern supports the idea of more independent change in the blade configuration that could be related to different factors, as life history (see Discussion).

\subsection{Morphospace occupation}

Tree distribution onto shape space suggests gradual displacement of diversification from left to right (Figure 7). The two main clades occupied different areas in the shape space. Projectile points characterized by blade contraction (depicted in blue colours) and stem expansion (depicted in red colours) are related to earlier evolved shapes, while the ones with expanded blades and contracted stems are linked to more derived ones (more distant to the root) (Figure 7).

Projectile points characterized by blade contraction (i.e. shorter and wider blades depicted in blue colours) and stem expansion (i.e. bigger stems depicted in red colours) are related to earlier evolved shapes (like G1, G3, G6, G10, G11 and G12), while the ones with expanded blades (i.e. longer and narrow blades in red colours) and contracted stems (i.e. smaller ones in blue colours) are linked to more derived ones (more distant to the root, like G4, G5, G8 and G9 )

The phylogeny displacement within the morphological space does not show overlap or tangle between the branches, suggesting a gradual shift from one morphospace sector to another, where different traits of total shape evolves.

Finally, the Mantel correlation between cophenetic distance and mean spatial coordinates of each group yields not significant results $(\mathrm{r}=-0.25, \mathrm{p}>0.05)$. These results contrast with previously observed patterns (Cardillo \& Charlin 2016), where a correlation between both distances was observed, which may be due to different factors (see Discussion). 


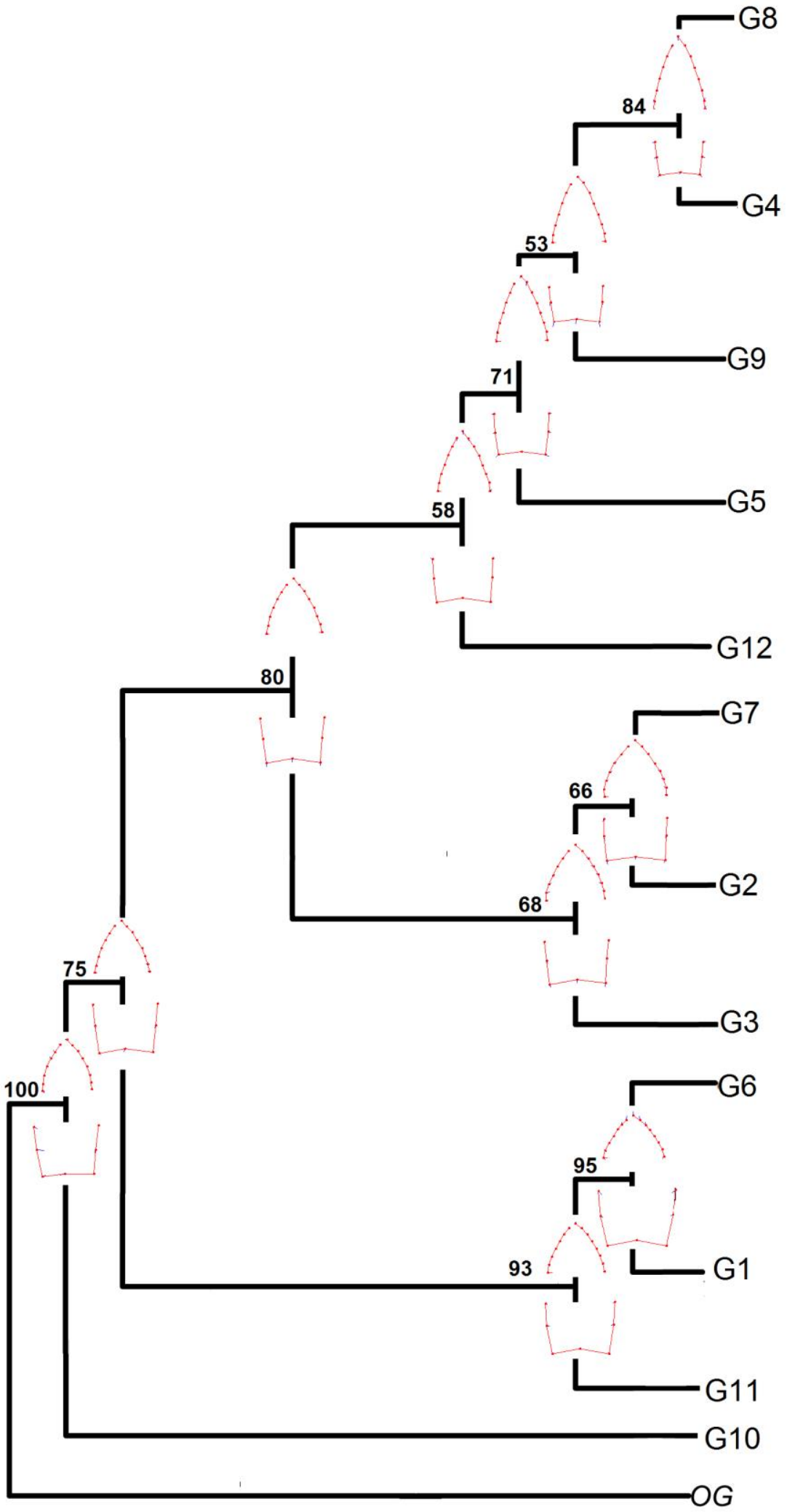

Figure 6. Maximum parsimony tree showing ancestral configuration for blade and stem and the frequency of bootstrap support for each node. 


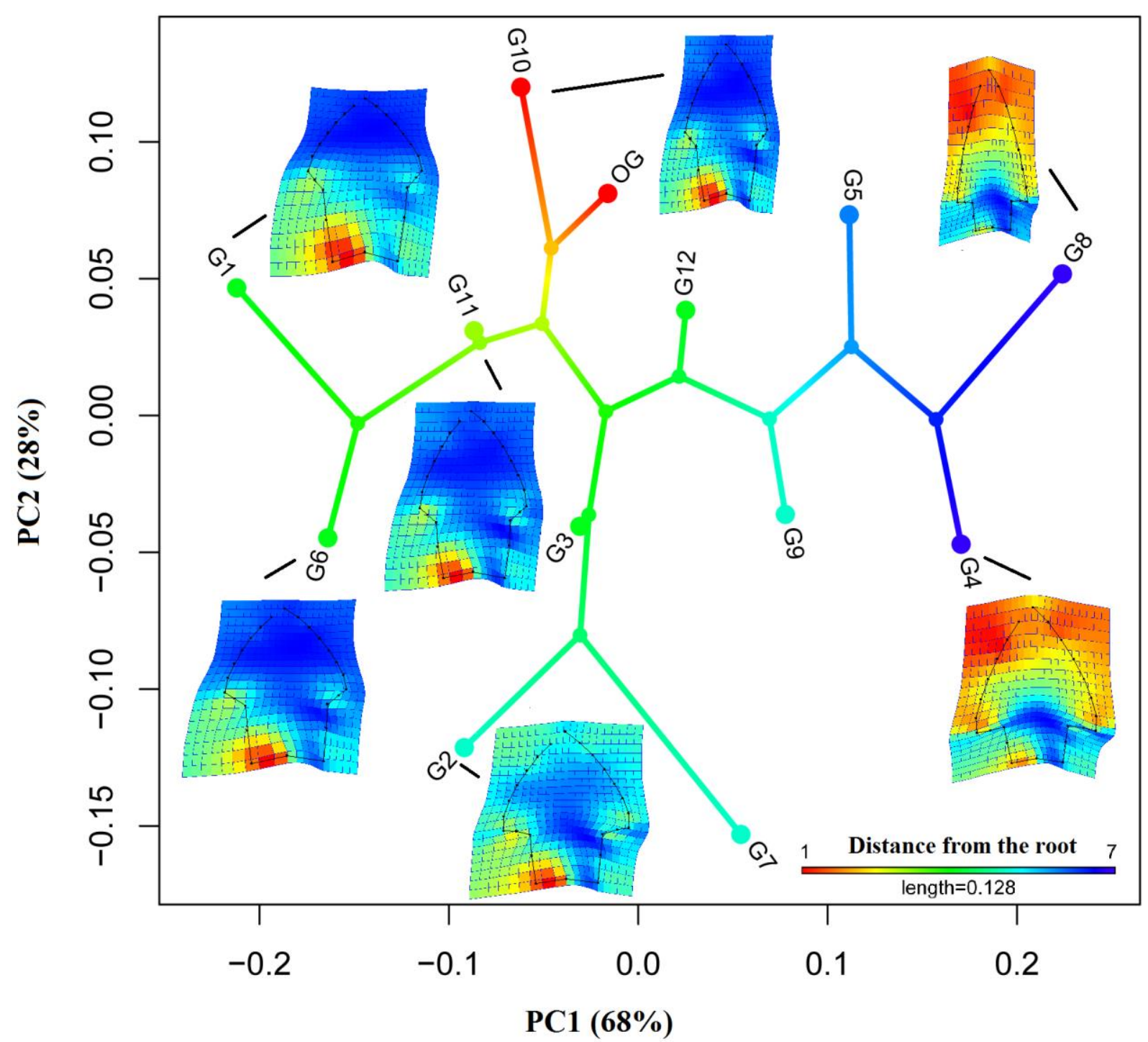

Figure 7. Phylomorphospace plot showing the diversification pattern on shape space using the resolved tree (Figure 4A). Branch colour shows distance to the root. Thin plate spline reconstructed shapes represent deformation between out-group and tips.

\section{Discussion}

The results obtained support previous hypothesis on the existence of a phylogenetic signal in the lithic projectile points from continental Patagonia. General pattern suggests that projectile points with smaller stems and elongated blades evolve later, which is consistent with the existing archaeological information, which relates this type of points as belonging to release systems by means of bows (Banegas et al. 2014; Bettinger \& Eerkens 1999; Bird 1988; González-José \& Charlin 2012; Ratto 1994; Shott 1993; 1997). Increasing sample size and the statistical based definition of projectile point classes allowed us to model lineage diversity through time and explore its relation with the shape evolution. Indeed branching pattern of phylogeny within the shape space is consistent with this idea, and suggests that both sectors of the morphospace were occupied at different times and gradually filled, although in a relatively homogeneous way. We believe that changes in morphospace occupation are related with a functional dimension, showing the evolution of different weapon systems along the Holocene. As Lyman et al. (2008) observed, the increase of the total variation is compatible with the appearance of new technologies, where the design space (sensu Stankiewicz 2000) changes, whenever the functional requirements also changed. 
On the other hand, the bootstrap consensus tree of $\mathrm{NJ}$ points out to the existence of homoplasy in some clades, in particular those closest to the tree root. It is feasible that this homoplasy is related to the fact that some of the OTUs belong to a morphological continuum linked to the allometric trajectories followed by the designs throughout their life history, as was suggested previously as a source for potential convergence in projectile point shapes (Charlin \& Cardillo 2018).

It is also interesting to note that both methods result in similar topologies, although the support values for the tree obtained by MP are higher. These results are in agreement with what was observed by Catalano \& Torres (2016) and we also observe in previous research (Cardillo \& Charlin 2016: 265). The authors carried out comparative studies of phylogenetic reconstruction with different methods in 41 shape datasets and observed that MP and NJ generated trees with similar topologies in all cases (Catalano \& Torres 2016).

This method also allowed reconstructing the expected morphologies for the different nodes of the tree. Although both configurations have relevant synapomorphies, estimation of overall homoplasy indicates that on the blade is 2.41 times higher than on the stem, a pattern also recognized by other methods (Charlin \& González-José 2012). As previously mentioned, the case study of morphological change trajectories for three classes of stemmed points commonly differentiated in Late Holocene southern Patagonia (IV and V Fell-, Magallanesor Bird- types and Ona type sensu Bird 1938, 1946, 1988), indicated that there was a high potential for convergence throughout life history. In this way, although they differ in size and shape at the beginning of their lifespan, these point types tend to converge in shape as the rejuvenation process advances (Charlin \& Cardillo 2018; Charlin \& González-José 2012). For this reason, it is expected that some classes show different degrees of reactivation and allometric trajectories. Also is possible that these differences are due to modifications that occurred during the life history and that do not have a hereditary component while others do. This issue and the way to deal with are still in discussion from Gould (1985) "Ontogeny and Phylogeny" book to the present. However, take into account these factors (in particular heritable changes in development time or heterochrony) need further research. Independent measures of reduction could be obtained for each projectile point and then map the degree of reduction intensity detected on the resolved phylogeny. It is to be expected that if the use-life generates convergence or parallelism between classes, differences between each clade that are not present in the immediate common ancestor (and that can then be confused as an evolutionary novelty, an apomorphy) will be observed. Taking into account different configurations, however, can be used as a first step to estimate the degree of homoplasy in this character.

Considering the pattern of diversification observed through the reconstruction of the number of lineages in relation to the evolutionary time of the tree, two hypotheses can be proposed: a first scenario of initial cladogenesis followed by a relatively high rate of diversification and a later fall-off when averaging the evolutionary time (resolved tree Figure 4 A) or a rapid initial diversification followed by a sudden descent (consensus tree Figure 4 B). This second scenario regards the uncertainty in the resolution of the tree, linked to the potential convergence and homoplasy of the OTUs. Considering homoplasy or not, both patterns are consistent with what was previously observed, where the largest diversification event was located close to the root (Cardillo \& Charlin 2016). In relation to this possible pattern, it is interesting to note that it is probably the most commonly observed in biological phylogenies. Hughes et al. (2013) suggest that the greatest biological variety (disparity) tends to occur early in the process of diversification, possibly related to the emergence of key innovations that are then shared by all members of the descendant clade. In technological terms, it is compatible with the generation of a basic set of different shape features (like the combination of more rounded blades with expanded stems or sharp blades with contracted 
stems), which in turn, could play as structuring factors in the subsequent diversification process.

With respect to the relationship between space and phylogeny, the new results are not in agreement with the previously observed spatial pattern of two main clades in northern and southern Patagonia (Cardillo \& Charlin 2016). We believe that one of the main causes is that the larger spatial coverage reduces the contrast between the extreme north and south of Patagonia, where the largest differences seem to be located, as other lines of evidence have also suggested. However, we believe that this model of isolation by distance, as it was previously defined (Cardillo \& Charlin 2006), should be put into contrast again considering other sectors of space (such as Tierra del Fuego, in insular Patagonia), or using spatially based methods for the definition of morphological groups. These issues "shape" our upcoming research agenda.

\section{Conclusions}

The aim of this paper was to perform a detailed analysis of shape diversification pattern and morphospace occupation for stemmed projectile points of late Middle and Late Holocene of Argentinean Patagonia by means of statistical and cladistic methods.

Results suggest both NJ and MP methods successfully detect a phylogenetic signal in projectile point shape data. The observed pattern support previous results that projectile points with longer and narrow blades and smaller stems evolved later in Patagonia and occupy a different sector of morphospace that could be related to the emergence of different technical systems like bow and arrow. Also, basic elements of shape configurations seem to have evolved more or less quickly, what was later manifested as a relative reduction in the rate of morphological innovation of divergent lineages that occupied the shape design space in a relatively homogeneous way. However, the relationship of shape divergence with spatial distance is not more supported in actual results. Finally, results support the idea that the average blade shape could carry a clear phylogenetic signal although it is expected that it contains greater independent changes related to life history.

Future analyses need to explore in more detail the role of design, performance and life history in the evolution of different projectile point classes. This could be done including results of regression between allometric trajectories into phylogenetic models.

\section{Acknowledgements}

We want to thank to Michael O'Brien and Michael Shott for their careful reading of our manuscript and their many insightful comments and suggestions that help us to improving it. Also we want to thank to Otis Crandell and Journal of Lithic Studies editors.

The survey of museum collections was funded by Consejo Nacional de Investigaciones Científicas y Técnicas and Fondo Nacional de la Artes (Ministerio de Cultura, Presidencia de la Nación). We specially acknowledge Flavia Morello, Fabiana Martin and Pedro Cárdenas from Instituto de la Patagonia (Universidad de Magallanes, Chile), Eduardo Pérez Navarro from Museo de la Patagonia "F.P. Moreno" (San Carlos de Bariloche, Prov. Río Negro, Argentina) and Alejandra Reynoso and Marina Marchegiani from Museo Etnográfico "J.B. Ambrosetti" (Ciudad Autónoma de Buenos Aires, Argentina) for the access to Patagonian projectile point collections. This work is the result of our research in the frame of PICTANPCyT 2015-0411 "Variaciones morfométricas de las puntas de proyectil de FuegoPatagonia: experimentación, colecciones de museo y morfometría geométrica 3D", which unfortunately has recently been stopped to funding by the economic situation of Argentina. 


\section{References}

Adams, D., Rohlf, F.J. \& Slice, D., 2013, A field comes of age: Geometric morphometrics in the 21th century. Hytrix, the Italian Journal of Mammalogy, 24(1): 7-14. doi:10.4404/hystrix-24.1-6283

Alberti, J. \& Cardillo, M., 2015, Primary and secondary lithic raw material sources along the western coast of San Matías Gulf (Río Negro province, Argentina): A first approach to their spatial variability. Quaternary International, 373: 63-71. doi:10.1016/j.quaint.2014.09.061

Alberti, J. \& Fernández, M.V., (Eds.), 2015, Materias primas líticas en Patagonia: Localización, circulación y métodos de estudio de las fuentes de rocas de la Patagonia argentino-chilena. Intersecciones en Antropología, Special Issue 2, Universidad nacional del Centro de la provincial de Buenos Aires. Olavarría, Argentina, 153 p. (in Spanish) ("Lithic raw materials in Patagonia: Location, circulation and methods of study of stone sourcing of the Argentine-Chilean Patagonia")

Álvarez, M. 2011, Puntas de arma del extremo sur de Patagonia: Algunas consideraciones sobre diseño y contexto de uso. In: Armas prehispánicas: Múltiples enfoques para su estudio en Sudamérica (Martínez, J.G. \& Bozzutto, D.L., Eds.), Fundación de Historia Natural Félix de Azara, Buenos Aires: p. 15-36. (in Spanish) ("Weapon points from Southernmost Patagonia: Some considerations about design and use context")

Anderson, M.J. 2001, A new method for non-parametric multivariate analysis of variance. Austral Ecology, 26: 32-46. doi:10.1111/j.1442-9993.2001.01070.pp.x

Andrefsky, W. Jr. 2006, Experimental and archaeological verification of an index of retouch for hafted bifaces. American Antiquity, 71: 743-757. doi:10.2307/40035887

De Azevedo, S., Charlin, J., \& González-José, R. 2014, Identifying design and reduction effects on lithic projectile point shapes. Journal of Archaeological Science, 41: 297307. doi:10.1016/j.jas.2013.08.013

Banegas, A., Gómez Otero, J., Goye, S., \& Ratto, N., 2014, Cabezales líticos del Holoceno tardío en Patagonia meridional: Diseños y asignación funcional. Magallania, 42(2): 155-174. (in Spanish) ("Lithic heads of Late Holocene in Southern Patagonia: Designs and functional assignation”) doi:10.4067/S0718-22442014000200009

Barberena, R. 2002, Los límites del mar. Isótopos estables en Patagonia Meridional. Colección Tesis de Licenciatura, Sociedad Argentina de Antropología, Buenos Aires, 134 p. (in Spanish) ("The sea borders. Stables isotopes in Southern Patagonia")

Barberena, R., 2008, Arqueología y biogeografía humana en Patagonia Meridional. Sociedad Argentina de Antropología, Buenos Aires, 395 p. (in Spanish) (“Archaeology and human biography in Southern Patagonia")

Barberena, R., Zangrando, A.F., Gil, A., Martínez, G., Politis, G., Borrero, L., \& Neme, G., 2009, Guanaco (Lama guanicoe) isotopic ecology in southern South America: Spatial and temporal tendencies, and archaeological implications. Journal of Archaeological Science, 36: 2666-2675. doi:10.1016/j.jas.2009.08.003

Basalla, G. 1988, The Evolution of Technology. Cambridge University Press, Cambridge, $248 \mathrm{p}$. 
Beck, Ch. 1998, Projectile point types as valid chronological units. In: Unit issues in archaeology-measuring time, space, and material (Ramenofsky, A., \& Steffen, A., Eds.), University of Utah Press, Salt Lake City: p. 21-40.

Bettinger, R. L., \& Eerkens, J. 1999, Point typologies, cultural transmission, and the spread of bow-and-arrow technology in the prehistoric Great Basin. American Antiquity, 64(2): 231-242. doi: $10.2307 / 2694276$

Bettinger, R., O’Connell, J., \& Thomas, D. 1991, Projectile points as time markers in the Great Basin. American Anthropologist, 93: 166-172. doi:10.1525/aa.1991.93.1.02a00140

Bird, J. 1938, Antiquity and migrations of the early inhabitants of Patagonia. Geographical Review, 28: 250-275. doi:10.2307/210474

Bird, J. 1946, The archaeology of Patagonia. In: Handbook of South American Indians, Vol. I (Steward, J. H., Ed.), Smithsonian Institution, Bureau of American Ethnology, Washington: p. 17-24.

Bird, J. 1988, Travels and archaeology in south Chile. University of Iowa Press, Iowa City, $246 \mathrm{p}$.

Bookstein, F. 1991, Morphometric tools for landmark data. Geometry and biology. Cambridge University Press, New York, 435 p. doi:10.1002/bimj.4710350416.

Bookstein, F. 1997, Landmarks methods for form without landmarks: Morphometrics of group differences in outline shape. Medical Image analysis, 1(3): 225-243. doi:10.1016/S1361-8415(97)85012-8

Borrazzo, K. 2012, Raw material availability, flaking quality and hunter-gatherer decision making in Northern Tierra del Fuego Island (Argentina). Journal of Archaeological Science, 39: 2643-2654. doi:10.1016/j.jas.2012.03.018

Borrero, L.A. 1994-1995, Arqueología de la Patagonia. Palimpsesto, 4: 9-69. (in Spanish) (“Archaeology of Patagonia")

Borrero, L.A. 2001, Cambios, continuidades, discontinuidades: Discusiones sobre arqueología Fuego-Patagónica. In: Historia Argentina Prehispánica (Berberián, E., \& Nielsen, A., Eds.), Editorial Brujas, Córdoba: p. 815-838. (in Spanish) ("Changes, continuities, discontinuities: Discussions about Fuego-Patagonian Archaeology”)

Borrero, L.A. 2015, Con lo mínimo: los debates sobre el poblamiento de América del Sur. Intersecciones en Antropología, 16(1), 5-38. (in Spanish) ("With the minimum: The debates about the peopling of South America")URI: http://hdl.handle.net/11336/41275

Borrero, L.A., \& Barberena, R. 2006, Hunter-gatherer home ranges and marine resources. Current Anthropology, 47(5): 855-867. doi:10.1086/507186

Borrero, L.A., \& Franco, N. 1997, Early Patagonian hunter-gatherers: Subsistence and technology. Journal of Anthropological Research, 53: 219-239. doi:10.1086/jar.53.2.3631277

Borrero, L. A., Guichón, R., Tykot, R., Kelly, J., Prieto, A., \& Cárdenas, P. 2001, Estudios de dieta por medio de isótopos estables sobre huesos humanos de Patagonia Meridional y Tierra del Fuego. Anales del Instituto de la Patagonia, 29: 119-127. (in Spanish) ("Diet studies by means of stables isotopes on human bones from southern Patagonian and Tierra del Fuego") 
Bradbury, A., \& Carr, P. 2003, A method for quantifying size and shape dimensions of North American hafted biface. In: Lithic analysis at the millennium (Moloney, N., \& Shott, M., Eds.), Institute of Archaeology, London: p. 173-187.

Buchanan, B. 2006, An analysis of Folsom projectile point resharpening using quantitative comparisons of form and allometry. Journal of Archaeological Science, 33: 185-199. doi:10.1016/j.jas.2005.07.008

Buchanan, B., \& Collard, M. 2010, A geometric morphometric-based assessment of blade shape differences among Paleoindian projectile point types from western North America. Journal of Archaeological Science, 37: 350-359. doi:10.1016/j.jas.2009.09.047

Buchanan, B., O’Brien, M.J, \& Collard, M. 2014, Continent-wide or region-specific? A geometric morphometrics-based assessment of variation in Clovis point shape. Archaeological and Anthropological Science, 6(2): 145-162. doi:10.1007/s12520-0130168-x

Buchanan, B., Eren, M., Boulanger, M., \& O’Brien, M. 2015, Size, shape, scars, and spatial patterning: A quantitative assessment of late Pleistocene (Clovis) point resharpening. Journal of Archaeological Science: Reports, 3: 11-21. doi:10.1016/j.jasrep.2015.05.011

Cardillo, M. 2009, Temporal trends in the morphometric variation of the lithic projectile points during the middle holocene of southern andes (Puna region). A coevolutionary approach. In: Theoretical and methodological issues in evolutionary archaeology: toward an unified Darwinian paradigm (Lopez, G., \& Muscio, H., Eds.), British Archaeological Reports series,Vol. 20, Archaeopress, Oxford: p. 13-20.

Cardillo, M. 2010, Some applications of geometric morphometrics to archaeology. In: Morphometrics for nonmorphometricians (Elewa, A., Ed.), Springer, Verlag, BerlinHeidelberg: p. 325-355. doi:10.1007/978-3-540-95853-6

Cardillo, M. 2011, Exploring latitudinal patterns of lithic technology variation in continental coastal Patagonia, Argentina. Journal of Archaeological Science, 38(10): 2675-2682. doi:10.1016/j.jas.2011.06.004

Cardillo, M., \& Alberti, J. 2015, The evolution of projectile points and technical systems: A case from northern Patagonian coast (Argentina). Journal of Archaeological Science Reports, 2: 612-623. doi:10.1016/j.jasrep.2014.11.005

Cardillo, M., \& Charlin, J. 2016, Morphological diversification of stemmed projectile points of Patagonia. Assessing spatial and environmental patters by means of phylogenies and comparative methods. In: Multidisciplinary approaches to the study of stone age weaponry (Iovită, R., \& Sano, K., Eds.), Vertebrate Paleobiology and Paleoanthropology Book Series, Springer, Dordrecht: p. 261-272. doi:10.1007/978-94017-7602-8_18

Cardillo, M., Borrazzo, K., \& Charlin, J. 2016, Environment, space, and morphological variation of projectile points in Patagonia (southern South America). Quaternary International, 422: 44-56. doi:10.1016/j.quaint.2015.11.134

Castiñeira, C., Charlin, J., Cardillo, M., \& Baeza, J. 2012, Exploring morphometric variations in Fishtail projectile points from Uruguay, Pampa and Patagonia. In: Southbound: Late Pleistocene peopling of Latin America, Part 2, (Miotti, L., Salemme, M., Flegenheimer, N., \& Goebel, T., Eds.), Center for the Study of the First Americans, Department of Anthropology, Texas: p. 57-62. 
Catalano, S.A., Goloboff, P.A., \& Giannini, N.P. 2010, Phylogenetic morphometrics (I): The use of landmark data in a phylogenetic framework. Cladistics, 26: 539-549. doi:10.1111/j.1096-0031.2010.00302.x

Catalano, S.A., Ercoli, M., \& Prevosti, F. 2015, The more, the better: The use of multiple landmark configurations to solve the phylogenetic relationships in Musteloids. Systematic Biology, 64: 294-306. doi:10.1093/sysbio/syu107

Cavalli-Sforza, L., \& Feldman, M. 1981, Cultural transmission and evolution: A quantitative approach. Princeton University Press, Princeton: 388 p.

Charlin, J. 2009, Estrategias de aprovisionamiento y utilización de las materias primas líticas en el campo volcánico Pali Aike (Prov. Santa Cruz, Argentina). British Archaeological Reports International Series Vol. 1901, Archaeopress, Oxford, 249 p. (in Spanish) ("Lithic raw materials procurement and utilization strategies at Pali Aike volcanic field (Santa Cruz Province, Argentina)")

Charlin, J., \& L.A. Borrero. 2012, Rock art, inherited landscapes and human populations in southern Patagonia. In: A companion to rock art (McDonald, J., \& Veth, P., Eds.), Wiley-Blackwell, Hoboken: p. 381-397. doi:10.1002/9781118253892.ch22

Charlin, J., \& Cardillo, M. 2018, Reduction constraints and shape convergence along tool ontogenetic trajectories. In: Convergent evolution in stone-tool technology (O'Brien, M., Buchanan, B., \& Eren, M., Eds.), Vienna Series in Theoretical Biology, MIT Press, Cambridge, MA: p. 109-129.

Charlin, J., \& González-José, R. 2012, Size and shape variation in Late Holocene projectile points of southern Patagonia. A geometric morphometric study. American Antiquity, 77(2): 221-242. doi:10.7183/0002-7316.77.2.221

Charlin, J., Borrazzo, K. \& Cardillo, M. 2013, Exploring size and shape variations in late Holocene projectile points from northern and southern coasts of Magellan Strait (South America). In: Understanding landscapes, from land discovery to their spatial organization / Le franchissement des détroits et des bras de mer aux périodes pré-et protohistoriques (Djinjian, F., \& Robert, S., Eds.), British Archaeological Reports, International Series 2541, Archaeopress, Oxford: p. 39-50

Charlin, J., Borrero, L.A., \& Pallo, M.C. 2011, Ocupaciones humanas en el área noroccidental del río Gallegos (Prov. de Santa Cruz, Argentina). In: Bosques, montañas y cazadores. Investigaciones arqueológicas en Patagonia Meridional (Borrero, L., \& Borrazzo, K., Eds.), Consejo Nacional de Investigaciones Científicas y Técnicas- Instituto Multidisciplinario de Historia y Ciencias Humanas, Buenos Aires: p. 179-210. (in Spanish) ("Human occupations in the northwestern area of Gallegos river (Santa Cruz Province, Argentina)")

Charlin, J., Cardillo, M., \& Borrazzo, K. 2014, Spatial patterns in Late Holocene lithic projectile point technology of Tierra del Fuego (southern South America): Assessing size and shape changes. World Archaeology, 46(1): 78-100.

doi:10.1080/00438243.2014.890914 
Cirigliano, N., Pallo, M.C. \& Charlin, J. 2018, Circulación y distribución de rocas de grano fino oscuras tipo Potrok Aike: Una comparación entre conjuntos líticos del extremo sur de Patagonia continental (Santa Cruz, Argentina). In: Proceeding of the First Argentinean Conference of Lithic Studies in Archaeology, September 19-22 2018, Córdoba (Argentina). Universidad Nacional de Córdoba, Córdoba, Argentina, 1 p. (in Spanish) ("Circulation and distribution of dark fine grained rocks Potrok Aike type: a comparison between lithic assemblages of southernmost continental Patagonia (Santa Cruz, Argentina)".

URL: https://suquia.ffyh.unc.edu.ar/bitstream/handle/suquia/3000/9911Cirigliano\%20et\%20al..pdf

Charrad, M., N. Ghazzali., V. Boiteau, \& Niknafs, A. 2014, "NbClust: An R package for determining the relevant number of clusters in a data set." Journal of Statistical Software, 61: 1-36. doi:10.18637/jss.v061.i06

Clapperton, C. 1993, Quaternary geology and geomorphology of South America. Elsevier, Amsterdam, $779 \mathrm{p}$.

Collard, M. 2006, Branching, blending, and the evolution of cultural similarities and differences among human populations. Evolution and Human Behavior, 27(3): 169-184. doi:10.1016/j.evolhumbehav.2005.07.003

Dibble, H. 1984, Interpreting typological variation of Middle Paleolithic scrapers: Function, style, or sequence of reduction? Journal of Field Archaeology, 11: 431-436. doi:10.1179/jfa.1984.11.4.431

Dibble, H. 1987, The interpretation of Middle Paleolithic scraper morphology. American Antiquity, 52: 109-117.Dunnell, R. 1989, Systematics in prehistory. The Blackburn Press, Caldwell, New Jersey, 214 p. doi:10.2307/281062

Durham, W.H. 1992, Coevolution: Genes culture and human diversity. Stanford University Press, Stanford, Palo Alto, 656 p.

Flenniken, J., \& Raymond, A. 1986, Morphological projectile point typology: Replication, experimentation and technological analysis. American Antiquity, 51: 603-614. doi: $10.2307 / 281755$

Flenniken, J., \& Wilke, P. 1989, Typology, technology, and chronology of Great Basin dart points. American Anthropologist, 91: 149-158. doi:10.1525/aa.1989.91.1.02a00100

Franco, N. 2002. Estrategias de utilización de recursos líticos en la cuenca superior del Río Santa Cruz. Ph.D. thesis. Facultad de Filosofía y Letras, Universidad de Buenos Aires, Buenos Aires, 682 p.

Franco, N. 2008, La estructura tecnológica regional y la comprensión de la movilidad humana: Tendencias para la cuenca del río Santa Cruz. In: Arqueología del extremo sur del continente Americano (Borrero, L.A., \& Franco, N., Eds.), Consejo Nacional de Investigaciones Científicas y Técnicas-Instituto Multidisciplinario de Historia y Ciencias Humanas, Buenos Aires: p. 119-154. (in Spanish) ("The regional technological structure and the understanding of human mobility: Tendencies for the Santa Cruz river basin")

Franco, N., Cardillo, M. \& Borrero, L.A. 2005, Una primera aproximación a la variabilidad presente en las puntas denominadas "Bird IV". Werken, 6: 81-95. (in Spanish) ("A first approach to variability in points called "Bird IV") 
Franco, N., Castro, A., Cardillo, M., \& Charlin, J. 2009, La importancia de las variables morfológicas, métricas y de microdesgaste para evaluar las diferencias en diseños de puntas de proyectil bifaciales pedunculadas: Un ejemplo del sur de Patagonia continental. Magallania, 37(1): 99-112. (in Spanish) ("The importance of morphological, metrical and use-wear variables to assess design differences in bifacial stemmed projectile points: An example from continental southern Patagonia")

Franco, N., Gómez Otero, J., Guráieb, G., Goye, S., Cirigliano, N., \& Banegas, A. 2010, Variaciones espaciales en diseños de puntas pedunculadas medianas en Patagonia Argentina: Una nueva aproximación. In: Arqueología Argentina en el bicentenario de la revolución de Mayo, Vol. I (Bárcena, J.R., \& Chiavazza, H., Eds.), Universidad Nacional de Cuyo, Instituto de Ciencias Humanas, Sociales y Ambientales - Consejo Nacional de Investigaciones Científicas y Técnicas \& Agencia Nacional de Promoción Científica y Tecnológica (INCIHUSA-CONICET \& ANPCyT), Mendoza: p. 281-286. (in Spanish) ("Spatial variations in medium-sized stemmed point designs in Argentine Patagonia: A new approach")

Franco, N., Brook, G., Mancini, M.V., \& Vetrisano, L. 2016, Changes in lithic technology and environment in southern continental Patagonia: The Chico and Santa Cruz River basins. Quaternary International, 422: 57-65. doi:10.1016/j.quaint.2015.11.132

Goloboff, P.A., Farris, J.S., \& Nixon, K.C. 2008, TNT, a free program for phylogenetic analysis. Cladistics, 24: 774-786. doi:10.1111/j.1096-0031.2008.00217.x

Gómez Otero, J., Banegas, A., Goye, M.S., \& Franco, N.V. 2009, Variabilidad morfológica de puntas de proyectil en la costa centro-septentrional de Patagonia Argentina: Primeros estudios y primeras preguntas. In: Octavo Congreso de Historia Social y Política de la Patagonia Argentino-Chilena, Las fuentes en la construcción de una Historia Patagónica, Secretaría de Cultura de la Provincia del Chubut, Rawson: p. 110-118. (in Spanish) ("Morphological variability of projectile points from the central-northern coast of Patagonia")

González-José, R., \& Charlin, J. 2012, Relative importance of modularity and other morphological attributes on different types of lithic point weapons: Assessing functional variations. PLoS ONE , 7(10): e48009. doi:10.1371/journal.pone.0048009

Gould, S.J. 1989, A developmental constraint in Cerion, with comments on the definition and interpretation of constraint in evolution. Paleobiology, 43(3): 516-539. doi:10.1111/j.1558-5646.1989.tb04249.x

Gunz, P., \& Mitteroecker, P. 2013, Semilandmarks: A method for quantifying curves and surfaces. Hystrix, the Italian Journal of Mammalogy, 24(1): 103-106. doi:10.4404/hystrix-24.1-6292

Gunz, P., Mitteroecker,P., \& Bookstein, F. 2005, Semilandmarks in three dimensions. In: Modern morphometrics in physical anthropology (Slice, D., Ed.), Universidad de Chicago, Chicago: p. 73-98. doi:10.1007/0-387-27614-9_3

Hammer, Ø., Harper, D.A.T., \& Ryan, P.D. 2001, PAST: Paleontological Statistics Software Package for education and data analysis. Palaeontologia Electronica, 4(1): 1-9. URL: http://palaeo-electronica.org/2001_1/past/issue101.htm 
Hermo, D., \& Terranova, E. 2012, Formal variability in fishtail projectile points of Amigo Oeste archaeological site, Somuncurá plateau (Río Negro, Argentina). In: Southbound: Late Pleistocene peopling of Latin America (Miotti, L., Salemme, M., Flegenheimer, N., \& Goebel, T., Eds.), Current Research in the Pleistocene Special Edition Center for the study of the First Americans, Texas: p. 121-125.

Hermo, D., Terranova, E., \& Miotti, L. 2015, Tecnología y uso de materias primas en puntas Cola de pescado de la meseta de Somuncurá (provincia de Río Negro, Argentina). Chungará, 47(1): 101-115. (in Spanish) ("Technology and raw material use in Fishtail points from Somuncurá plateau (provincial de Río Negro, Argentina)") doi:10.4067/S0717-73562015005000005

Hiscock, P. 1994, The end of Points. In: Archaeology in the North (Sullivan, M., Ed.), North Australia Research Unit, Australian National University,Brinkin: p.72-83.

Hiscock, P. 2006, Blunt and to the point: Changing technological strategies in Holocene Australia. In; Archaeology in Oceania: Australia and the Pacific Islands (Lilley, I., Ed.), Blackwell, pp. 69-95. doi:10.1002/9780470773475.ch4

Hiscock, P. 2007, Looking the other way. A materialist/technological approach to classifying tools and implements, cores and retouched flakes. In: Tools versus Cores? Alternative approaches to Stone Tool Analysis (McPherron, S., Ed.), Cambridge Scholars Publishing, Newcastle, United Kingdom, pp. 198-222.

Hiscock, P, \& Attenbrow, V. 2002, Morphological and reduction continuums in eastern Australia: Measurement and implications at Capertee 3. Tempus, 7: 167-174.

Hiscock, P, \& Attenbrow, V. 2003, Early Australian implement variation: a reduction model. Journal of Achaeological Science, 30: 239-249. doi:10.1006/jasc.2002.0830

Hiscock, P., \& Attenbrow, V. 2005, Reduction continuums and tool use. In: Lithics 'Down Under': Recent Australian approaches to lithic reduction, use and classification (Clarkson, C., \& Lamb, L., Eds.), BAR International Series 1408, Oxford, pp. 43-55

Hiscock, P., \& Veth, P. 1991 Change in the Australian desert culture: A reanalysis of tulas from Puntutjarpa rockshelter. World Archaeology, 22: 332-345. doi:10.1080/00438243.1991.9980150

Hughes, S. 1998, Getting to the point: Evolutionary change in prehistoric weaponry. Journal of Archaeological Method and Theory, 5(4): 345-408. doi:10.1007/BF02428421

Hughes, M., Sylvain, G., \& Wills, M. A. 2013, Clades reach highest morphological disparity early in their evolution. Proceedings of the National Academy of Sciences, 1-5. doi:10.1073/pnas.1302642110.

Hunzicker, D. 2008, Folsom projectile technology: An experiment in design, effectiveness and efficiency. Plains Anthropologist, 53(207): 291-311. doi:10.2307/25671002

Iovită R. 2011, Shape variation in Aterian tanged tools and the origins of Projectile technology: A morphometric perspective on stone tool function. PLoS ONE, 6(12): e29029. doi:10.1371/journal.pone.0029029

Iovită, R., \& McPherron, S. 2011, The handaxe reloaded: A morphometric reassessment of Acheulian and Middle Paleolithic handaxes. Journal of Human Evolution, 61: 61-74. doi:10.1016/j.jhevol.2011.02.007 
Kitching, I., Forey, P., Humphries, C., \& Williams, D. 1998, Cladistics. The theory and practice of parsimony analysis. $2^{\text {nd }} \mathrm{ed}$. Systematics Association Publication 11. Oxford University Press, Oxford, 228 p.

Klingenberg, C.P. 2010, Evolution and development of shape: Integrating quantitative approaches. Nature Reviews Genetics, 11(9): 623-35. doi:10.1038/nrg2829

Klingenberg, C.P. \& Gidaszewski, N.A. 2010, Testing and quantifying phylogenetic signals and homoplasy in morphometric data. Systematic Biology, 59: 245-261. doi:10.1093/sysbio/syp106

Lycett, S., von Cramon-Taubadel, N., \& Gowlett, J. 2010, A comparative 3D geoemtric morphometric analysis of Victoria West cores: Implications for the origins of Levallois technology. Journal of Archaeological Science, 37: 1110-1117. doi:10.1016/j.jas.2009.12.011

Lycett, S., \& von Cramon-Taubadel, N. 2013, A 3D morphometric analysis of surface geometry in Levallois cores: Patterns of stability and variability across regions and their implications. Journal of Archaeological Science, 40: 1508-1517.

doi:10.1016/j.jas.2012.11.005

Lyman, R.L., VanPool, T.L., \& O'Brien, M.J. 2008, Variation in North American dart points and arrow points when one or both are present. Journal of Archaeological Science, 35: 2805-2812. doi:10.1016/j.jas.2008.05.008

McGhee, G. 1999, Theoretical morphology: The concept and its applications. Columbia University Press, New York, 378 p.

McGhee, G. 2015. Limits in the evolution of biological form: A theoretical morphologic perspective. Interface focus, 5: 20155534. doi:10.1098/rsfs.2015.0034

Massone, M. 1987, Los cazadores paleoindios de Tres Arroyos (Tierra del Fuego). Anales del Instituto de la Patagonia, 17: 47-60. (in Spanish) ("The paleoindian hunters of Tres Arroyos (Tierra del Fuego))

Massone, M. 2004, Los cazadores después del hielo. Colección de antropología Vol. 7. Museo de Historia Natural, Ediciones de la Dirección de Bibliotecas, Archivos y Museos, Santiago de Chile, 173 p. (in Spanish) ("The hunters after the ice")

Mengoni Goñalons, G.L. 1987, Modificaciones culturales y animales en los huesos de los niveles inferiores del sitio Tres Arroyos 1 (Tierra del Fuego, Chile). Anales del Instituto de la Patagonia, 17: 61-66. (in Spanish) ("Cultural and animal modifications in the bones from lower levels from the site Tres Arroyos 1 (Tierra del Fuego, Chile)")

Miotti, L. 1995, Piedra Museo locality: A special place in the New World. Current Research in the Pleistocene, 12: 37-40.

Miotti, L. 1996, Piedra Museo (Santa Cruz), nuevos datos para la ocupación Pleistocénica en Patagonia. In: Arqueología Solo Patagonia (Gómez Otero, J., Ed.), Centro Nacional Patagónico, Puerto Madryn: p. 93-101. (in Spanish) ("Piedra Museo (Santa Cruz), new data for Pleistocenic settlement in Patagonia")

Mitteroecker, P., \& Gunz, P. 2009, Advances in geometric morphometrics. Evolutionary Biology, 36: 235-247. doi:10.1007/s11692-009-9055-X

Mitteroecker, P., \& Hutteger, S. 2009, The concept of morphospaces in evolutionary and developmental biology: Mathematics and metaphors. Biological theory, 4(1): 54-67. doi:10.1162/biot.2009.4.1.54 
Morales, J., Soto, M., Lorenzo, C., \& Vergès, J. 2015, The evolution and stability of stone tools: The effects of different mobility scenarios in tool reduction and shape features. Journal of Archaeological Science: Reports, 3: 295-305. doi:10.1016/j.jasrep.2015.06.019

Morrow, J.E., \& Morrow, T.A. 2002, Exploring the Clovis-Gainey-Folsom continuum: Technological and morphological variation in midwestern fluted points. In: Folsom Technology and lifeways (Clark, J., \& Collins, M., Eds.), Lithic Technology, Special Publication no. 4, Tulsa, Oklahoma: p. 141-157.

Nami, H. 1985-1986, Excavaciones arqueológicas y hallazgo de una punta de proyectil "Fell I" en la "Cueva del Medio" seno de Ultima Esperanza, Chile. Anales del Instituto de la Patagonia, 16: 103-110. (in Spanish) ("Archaeological excavations and find of a "Fell I" projectile point in the "Cueva del Medio" Ultima Esperanza sound, Chile")

Nami, H. 1986, Experimentos para el estudio de la tecnología bifacial de las ocupaciones tardías en el extremo sur de Patagonia continental. PREP Informes de Investigación, 5: 1-120. (in Spanish) ("Experiments for the study of the bifacial technology from late settlement in the extreme south of continental Patagonia")

Nami, H. 1987, Cueva del Medio: Perspectiva arqueológica para la Patagonia Austral. Anales del Instituto de la Patagonia, 17: 73-106. (in Spanish) ("Cueva del Medio: Perspectives for austral Patagonia")

Nami, H. 1988, Arqueología experimental, tecnología, artefactos bifaciales y modelos. Estado actual del conocimiento en Patagonia y Tierra del Fuego. Anales del Instituto de la Patagonia, 18: 157-176. (in Spanish) ("Experimental archaeology, technology, bifacial artefacts and models. Current state of knowledge in Patagonia and Tierra del Fuego")

Nami, H. 2003, Experimentos para explorar la secuencia de reducción Fell de la Patagonia Austral. Magallania, 30: 107-138. (in Spanish) ("Experiments for exploring the Fell reduction sequence from southern Patagonia")

Nee, S., Holmes, E. C., Rambaut, A., \& Harvey, P. H. 1995, Inferring population history from molecular phylogenies. Philosophical Transactions of the Royal Society of London. Series B. Biological Sciences, 349: 25-31. doi:10.1098/rstb.1995.0087

O’Brien, M., Darwent, J., \& Lyman, R. 2001, Cladistics is useful for reconstructing archaeological phylogenies: Palaeoindian points from the southeastern United States. Journal of Archaeological Science, 28: 1115-1136. doi:10.1006/jasc.2001.0681

O’Brien, M., \& Lyman, R. 2003, Cladistics and archaeology. University of Utah Press, Salt Lake City, 304 p.

Okumura, M., \& Araujo, A. 2014, Long-term cultural stability in hunter-gatherers: A case study using traditional and geometric morphometric analysis of lithic stemmed bifacial points from southern Brazil. Journal of Archaeological Science, 45: 59-71. doi:10.1016/j.jas.2014.02.009

Orquera, L.A. 1987, Advances in the archaeology of the Pampas and Patagonia. Journal of World Prehistory, 1: 333-413. doi:10.1007/BF00974880 
Pallo. M.C. \& Cirigliano, N. Láminas y hojas vs. Lascas: una aproximación a la circulación diferencial de tecnologías implementadas en la manufactura artefactual y grupos poblacionales en Patagonia meridional. In: Proceeding of the First Argentinean Conference of Lithic Studies in Archaeology, September 19-22 2018, Córdoba (Argentina). (in Spanish) ("Blades vs. flakes: An approximation to the differential circulation of artefacts manufacture technologies and southern Patagonia populations") URL: http://suquia.ffyh.unc.edu.ar/handle/suquia/2983

Perez S.I., Bernal, V., \& González, P. 2006, Differences between methods to sliding semilandmarks: Its importance in human population analyses. Journal of Anatomy, 208(6): 769-784. doi:10.1111/j.1469-7580.2006.00576.x

Politis, G. 1991, Fishtail projectile points in the Southern Cone of South America: An overview. In: Clovis: Origins and adaptations (Bonnichsen, R., \& Turnmire, K., Eds.), Center for the Study of the Firts Americans, Orono: p. 287-301.

Prieto, A. 1991, Cazadores tempranos y tardíos en la cueva Lago Sofía 1. Anales del Instituto de la Patagonia, 20: 75-100. (in Spanish) ("Early and late hunters in tha Lago Sofía 1 cave")

R Development Core Team 2019, R: A Language and environment for statistical computing. R Foundation for Statistical Computing, Vienna. URL: http://www.r-project.org/

Ratto, N. 1990, Análisis funcional de las puntas de proyectil líticas del sitio Punta María 2 (Tierra del Fuego). Shincal, 3: 171-177. (in Spanish) ("Functional analysis of lithic projectile points from the site Punta María 2 (Tierra del Fuego)")

Ratto, N. 1991, Análisis funcional de las puntas de proyectil líticas de sitios del sudeste de la Isla Grande de Tierra del Fuego. Arqueología, 1: 151-178. (in Spanish) ("Functional analysis of lithic projectile points from southeast sites from the Isla Grande of Tierra del Fuego") URL: http://repositorio.filo.uba.ar/handle/filodigital/6937

Ratto, N. 1994, Funcionalidad vs. adscripción cultural: Cabezales líticos de la margen norte del estrecho de Magallanes. In: Arqueología de cazadores-recolectores. Límites, casos y aperturas (Lanata, J.L., \& Borrero, L.A., Eds.), Arqueología Contemporánea Vol. 5, Special Edition, Buenos Aires: p. 105- 120. (in Spanish) ("Functionality vs. cultural adscription: Lithic heads from the north margin of Magellan strait")

Restifo, F. 2013, Tecnología de caza durante el Holoceno temprano y medio en la Puna de la provincia de Salta (República Argentina): Patrones de variación y procesos de cambio. Comechingonia, Revista de Arqueología, 17(1): 59-84. (in Spanish) ("Hunting technology during early-middle Holocene in the Puna of Salta province (Argentina). Variation patterns and processes of change")

Rohlf, J. 2017, Relative warps (Version 1.69). Ecology \& Evolution and Anthropology, Stony Brook University, New York. URL: http://life.bio.sunysb.edu/morph/

Rohlf, J., \& Slice, D. 1990, Extensions of the Procrustes method for the optimal superimposition of landmarks. Systematic Zoology, 39(1): 40-59. doi:10.2307/2992207

Rohlf, F. 2004, TPSUtil. version 1.26. Department of Ecology and Evolution. New York: State University, Stony Brook.

Rohlf, F. 2007, TPSRelw version 1.45. Department of ecology and evolution, New York: State University, Stony Brook. 
Saitou, N., \& Nei, M. 1987. The neighbor-joining method: A new method for reconstructing phylogenetic trees. Molecular Biology and Evolution, 4(4): 406-425. doi:10.1093/oxfordjournals.molbev.a040454

Shott, M. 1993, Spears, darts, and arrows. Late Woodland hunting techniques in the Upper Ohio Valley. American Antiquity, 58: 425-443. doi:10.2307/282105

Shott, M. 1997, Stones and shafts redux. The metric discrimination of chipped-stone dart and arrow points. American Antiquity, 62(1): 86-101. doi:10.2307/282380

Shott, M. 2011, History written in stone: evolutionary analysis of stone tools in archaeology. Evolution: Education and Outreach, 4: 435-445. doi:10.1007/s12052-011-0344-3

Shott, M., \& Ballenger, J. 2007, Biface reduction and the measurement of Dalton curation: A southeastern United States case study. American Antiquity, 72: 153-175. doi: $10.2307 / 40035302$

Shott, M., \& Trail, B. 2010, Exploring new approaches to lithic analysis: Laser scanning and geometric morphometrics. Lithic Technology, 35(2): 195-220. doi:10.1080/01977261.2010.11721090

Shott, M., \& Trail, B. 2012, New developments in lithic analysis: Laser scanning and digital modeling. The SAA Archaeological Record, 12(3): 12-38.

URL: http://onlinedigeditions.com/publication/?i=113770\&article_id=1078624

Shott, M., Hunzicker, D., \& Patten, B. 2007, Pattern and allometric measurement of reduction in experimental Folsom bifaces. Lithic Technology, 32: 203-217. doi:10.1080/01977261.2007.11721054

Slice, D. 2007, Geometric morphometrics. Annual Review of Anthropology, 36: 261-281. doi:10.1146/annurev.antrhro.34.081804.120613

Stankiewicz, R. 2000, The concept of design space. Technological innovation as an evolutionary process. Cambridge University Press, New York, 234-247.

Sidlauskas, B. 2008, Continuous and arrested morphological diversification in sister clades of characiform fishes: A phylomorphospace approach. Evolution, 62: 3135-3156. doi:10.1111/j.1558-5646.2008.00519.x

Thulman, D. 2012, Discriminating Paleoindian point types from Florida using landmark geometric morphometrics. Journal of Archaeological Science, 39: 1599-1607. doi:10.1016/j.jas.2012.01.004

Towner, R.H., \& Warburton, M. 1990, Projectile point rejuvenation: A technological analysis. Journal of Field Archaeology, 17: 311-321. doi:10.1179/009346990791548231

Webster, M., \& Sheets, H.D. 2010, A practical introduction to landmark-based geometric morphometrics. In: Quantitative Methods in Paleobiology (Alroy, J. \& Hunt, G., Eds.), The Paleontological Society Papers, Volume 16. The Paleontological Society, Colorado: p. 163-188. doi:10.1017/S1089332600001868

Zelditch, M.L., Swiderski, D.L., Sheets, H.D., \& Fink, W.L. 2004, Geometric morphometrics for biologists - a primer. Elsevier, San Diego, 416 p. doi:10.1016/B978-0-12-7784601.X5000-5 


\title{
Análisis filogenético de las puntas pedunculadas de Patagonia: Cambio morfológico y evolución del morfoespacio
}

\author{
Marcelo Cardillo, Judith Charlin \\ Consejo Nacional de Investigaciones Científicas y Técnicas, Instituto Multidisciplinario de Historia y Ciencias \\ Humanas, Universidad de Buenos Aires, Saavedra 15 5th floor, 1083ACA, Ciudad Autónoma de Buenos Aires, \\ Argentina. Email: Cardillo: marcelo.cardillo@gmail.com; Charlin: judith.charlin@gmail.com
}

\section{Resumen:}

El presente trabajo se centra en el estudio de la variación morfológica de las puntas de proyectil líticas de Patagonia desde una perspectiva filogenética, persiguiendo tres objetivos principales: en primer lugar, generar un modelo sobre la diversificación morfológica y la evolución del espacio de forma; en segundo lugar, estimar la variación morfológica a través del tiempo y finalmente, evaluar la robustez de los resultados previos usando los mismos métodos pero en una muestra de mayor tamaño y cobertura espacial. A través de los métodos de morfometría geométrica y cladística, en un trabajo anterior se identificó la existencia de un patrón de diversificación morfológica de las puntas de proyectil a lo largo de Patagonia relacionado en parte a la distancia espacial entre casos, identificando dos clados principales en el norte $\left(43-45^{\circ} \mathrm{S}\right)$ y sur $\left(50-52^{\circ} \mathrm{S}\right)$ de Patagonia. Para estudiar este patrón en mayor detalle, en el presente trabajo se usó una muestra de ca. 1200 puntas de proyectil para obtener clases morfológicas diferentes estadísticamente. Con este fin se emplearon métodos de búsqueda automáticos (K-means clustering) y remuestreo sobre las coordenadas de forma generadas mediante el método de Procrustes. Este método procedimiento permitió definir 12 grupos estadístisticamente significativos $(\mathrm{p}<0.05)$.. Los caracteres morfológicos fueron usados para describir las diferentes unidades taxonómicas utilizando el promedio de forma (centroide) de cada uno de estos grupos y para realizar el análisis filogenético (mediante el método de Neighbour Joining y de Máxima Parsimonia) usando como ancestro el tipo de punta de proyectil más antiguo conocido para la región (Cola de Pescado). Los nuevos resultados sostienen la hipótesis de que existe una estructura filogenética en los cambios morfológicos en las puntas de proyectil de Patagonia a lo largo del tiempo. La aplicación de ambos procedimientos de reconstrucción filogenética arrojó similares resultados, aunque la resolución de los clados ha sido algo mejor en el caso de máxima parsimonia. En relación a este último método, la estimación de los niveles de homoplasia para los distintos sectores o módulos de la punta considerados (limbo y pedúnculo) señala que el limbo, si bien posee información filogenética, es también el carácter más conflictivo; ya que presenta los niveles de homoplasia más altos. Esto último puede vincularse con la historia de vida de los cabezales líticos. En términos generales, el patrón observado sugiere que las puntas con limbos más alargados y estrechos y pedúnculos pequeños evolucionaron más tardíamente en Patagonia, ocupando un sector diferente del espacio morfológico, lo cual puede estar relacionado a la emergencia de diferentes sistemas técnicos, como el arco y la flecha. Por otro lado, la temprana diversificación seguida por una disminución paulatina de la diversidad morfológica podría indicar que la mayor disparidad (entendida como diferencia entre las morfologías representadas por cada clase) se encontraría al inicio del proceso de diversificación, lo que es similar a lo observado en la evolución biológica. Asimismo, a diferencia de lo observado previamente, estos nuevos resultados no sostienen la hipótesis previa de un factor significativo en la diversificación morfológica explicado por la distancia espacial. Posiblemente esto 
se deba a una reducción de los contrastes entre el extremo norte y sur de Patagonia en relación con la mayor cobertura espacial utilizada en el presente análisis.

Palabras clave: puntas de proyectil pedunculadas; filogenia; morfometría geométrica; Patagonia; cambio morfológico; evolución 